\title{
Marine Isopod Crustaceans from Easter Island ${ }^{1}$
}

\author{
Brian Kensley ${ }^{2}$
}

\begin{abstract}
Isopods from 29 shallow-water stations around Easter Island were identified. Thirteen species in three suborders are described as new: suborder Anthuridea, Mesantbura pascuaensis, Saurantbura rapanui, Califantbura dodecaseta, Parantbura nordenstami; suborder Asellota, Foeropsis acoloris, foeropsis bicomis, Joeropsis limbatus, Foeropsis trilabes, Salvatiella islapascua, Uromunna biloba, Paramunna pellucida, Santia longisetae; suborder Flabellifera, Exosphaeroides quadricosta. Seven species were identified only to genus: Apantbura sp., Eisotbistos sp., Carpias sp., Maresiella sp., Metacirolana sp., Munna sp., Panathura sp. The shallow-water marine isopods show an endemism of over $90 \%$.
\end{abstract}

A collection of shallow-water marine isopod crustaceans made during two survey seasons on Easter Island in the South Pacific was offered to me for identification by Christopher Boyko of the American Museum of Natural History, New York. Because very few records of isopods exist for this most remote of locations, I accepted the offer with alacrity. The results of this study are presented here.

Isopods are one of the crustacean groups from Easter Island that have received little attention. The few previous records of this group are as follows: Two unidentified species of Dynamenella were recorded by DiSalvo et al. (1988) from nonliving coral; Botosaneanu (1987) described the blind anthurid isopod Cyatbura (Stygocyatbura) rapanuia from volcanic sand at midtide level on the shore; Boyko and Williams (2001) described a new species, Pseudionella akuaku, a parasitic bopyrid from the gill chamber of the hermit crab Calcinus imperialis.

\section{MATERIALS AND METHODS}

The material covered in this report was collected during two field seasons in 1998 and

\footnotetext{
${ }^{1}$ Manuscript accepted 15 September 2002.

${ }^{2}$ Department of Systematic Biology, National $\mathrm{Mu}-$ seum of Natural History, Smithsonian Institution, NHB163, P.O. Box 37012, Washington, D.C. 20013-7012.
}

Pacific Science (2003), vol. 57, no. 3:287-317

(C) 2003 by University of Hawai'i Press

All rights reserved
1999 as part of an invertebrate survey of Easter Island, funded by the U.S. National Park Service, Gateway National Recreation Area Division of Natural Resources, as part of a Science Museum of Long Island/Explorers Club 5-yr research expedition to explore the impacts of El Niño events on World Heritage Sites. Isopods were collected from 29 field stations, mostly in the intertidal region (see Figure 1 and Appendix). All the material is deposited in the American Museum of Natural History (AMNH), aside from a few duplicate paratypes deposited in the National Museum of Natural History, Smithsonian Institution (USNM).

The measurements provided are in all cases total length in millimeters, measured middorsally from tip of cephalon to tip of pleotelson.

\section{SYSTEMATICS}

Suborder ANTHuridea

Family Anthuridae

Genus Apanthura Stebbing, 1900

Apantbura sp.

Material examined: 2 immature + , Puu Kiri Ohio Point, Anakena Beach, coll. J. Quillen, 22 August 1998.

REMARKS: Because both specimens are immature and one is damaged, no further identification is possible.

Genus Mesantbura Barnard, 1914

Mesantbura pascuaensis Kensley, n. sp. Figure 2 


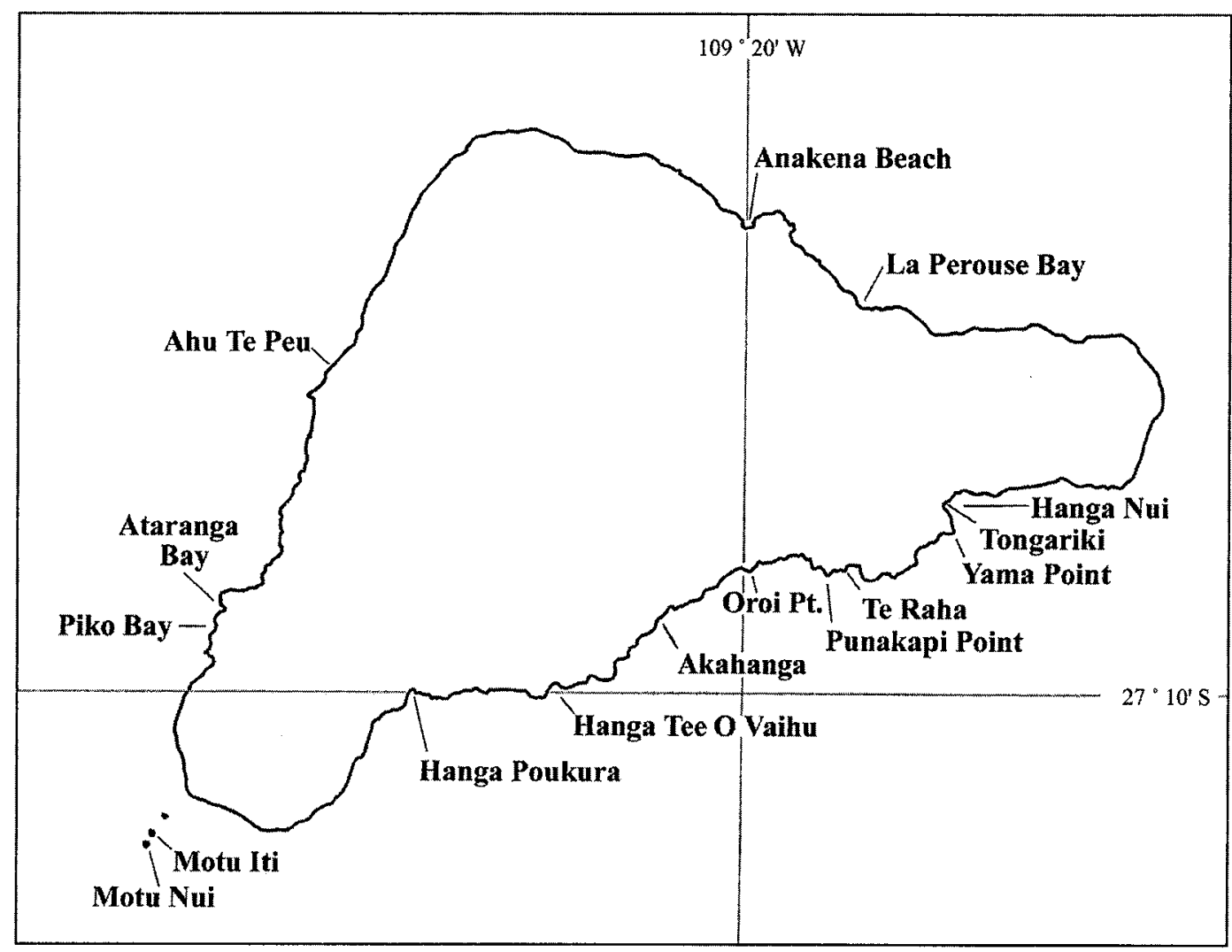

Figure 1. Map of Easter Island showing collecting localities.

MATERIAL EXAMINED: Holotype: AMNH 18382, 1 nonovigerous 오 $3.9 \mathrm{~mm}$, Piko Bay, from Pocillopora sp. coral, coll. C. Boyko and S. Reanier, 31 August 1999.

Description: Female: Body with strong dorsal pigmentation pattern. Cephalon shorter than pereonite 1 , with rounded anterolateral lobes reaching beyond rostral point. Pereonite 7 subequal in length to fused pleonites 1-5; pleonite 6 visible dorsally, lacking free lateral margins, with small median slit. Telson posteriorly setose, tapering to rounded apex.

Antennular flagellum of 3 articles, small terminal article bearing 3 aesthetascs. Antennal flagellum consisting of single setose article. Mandibular palp with articles 1 and 2 elongate, subequal, each bearing single elongate simple seta; article 3 short, with 3 distal setae; incisor with 3 cusps, lamina dentata of 6 teeth; molar blunt. Maxilliped lacking endite, with 6 setae in angle between terminal and subterminal articles. Pereopod 1, carpus triangular, with distal acute transparent lobe; propodal palm with transparent tooth in proximal half, few setae on palmar margin. Pereopod 2, carpus triangular, distally rounded; propodal palm bearing row of fringed scales plus stout posterodistal denticulate seta. Pereopods 4-7, carpus having free anterior margin shorter than posterior; propodus almost 3 times longer than wide, with row of fringed scales on posterior margin, 3 denticulate setae posterodistally; dactylus with row of fringed scales on posterior margin. Pleopod 1, opercular exopod with about 19 plumose marginal setae, about 2.2 times longer than greatest width; endopod less 


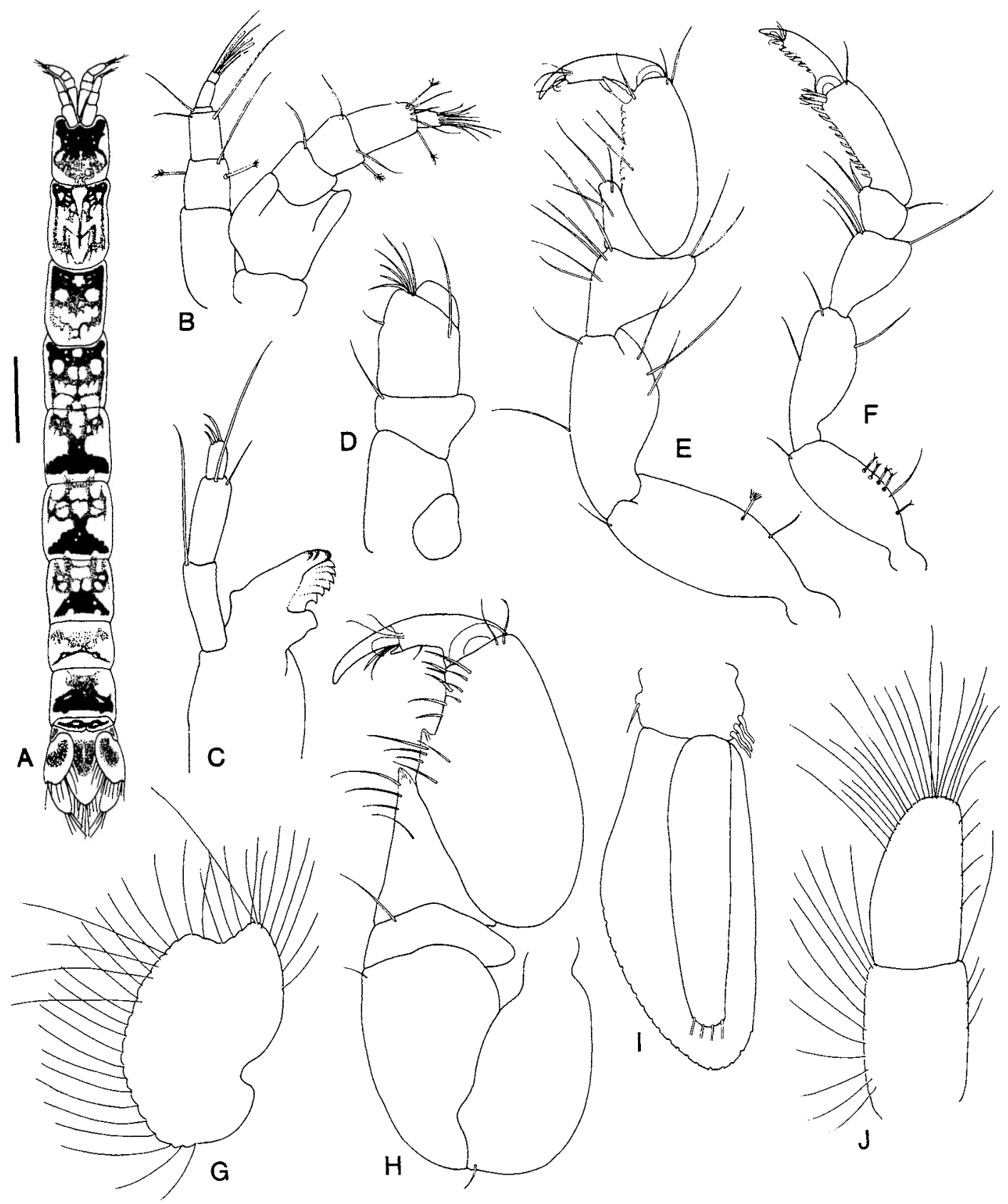

Figure 2. Mesantbura pascuaensis, n. sp. $A$, Holotype in dorsal view, scale $=0.5 \mathrm{~mm}$; $B$, antennule and antenna; $C$, mandible; $D$, maxilliped; $E$, pereopod $2 ; F$, pereopod $7 ; G$, uropodal exopod; $H$, pereopod $1 ; I$, pleopod $1 ; 7$, uropodal endopod. 
than half width and 0.9 times length of exopod, with 4 distal plumose marginal setae; uropodal exopod ovate, with strong distal emargination, margin bearing numerous plumose setae; endopod elongate-ovate, twice longer than basal width, distally broadly rounded and setose.

Color pattern: Reticulate bilaterally symmetrical pigment on cephalon, pereonites, and pleon, that of anterior half of cephalon almost black, of pereonites 1-3 with anterior part darker than posterior, of pereonites 4-6 with black transverse band in posterior half; pereonite 7 with faint slender transverse band; pleon with dark transverse band in posterior half; pleonite 6 with transverse band; patches of pigment on uropodal exopods and anterior telson.

REMARKS: There are no records of species of Mesantbura from the southern Pacific Ocean aside from those recorded from distant Australia. Mesantbura bieroglypbica Miller \& Menzies, 1952, from Hawai ${ }^{\circ}$, and $M$. cbildi Kensley, 1979, from Fiji, are each several thousand kilometers from Easter Island. Neither shows any similarity to $M$. pascuaensis in their color pattern. It is not surprising that this Mesantbura species from remote Easter Island is undescribed, and it is probably endemic to this island.

ETYMology: The specific name derives from the Spanish name for Easter Island.

Genus Sauranthura Poore \& Kensley, 1981

Sauranthura rapanui Kensley, n. sp.

Figure 3

MATERIAL EXAMINED: Holotype: AMNH 18383, 1 nonovigerous +, $1.8 \mathrm{~mm}$, sta. 2.3, Hanga Poukura, coll. A. Pianetti, 20 August 1998. Paratype: AмN H 18384, 1 nonovigerous ㅇ, $1.6 \mathrm{~mm}$ (dissected on slide), sta. 4.2, Akahanga, coll. A. Pianetti, 20 August 1998. Paratypes: UsNM 1009134, 2 nonovigerous $?$, $1.9 \mathrm{~mm}, 1$ damaged, sta. 8.1, Yama Point, off Tongariki, coll. J. S. Friedman, 21 August 1998.

DESCRIPTION: Female: Body about 6 times longer than greatest width at pereonite 5. Cephalon slightly wider than long, with broadly rounded rostrum. Pereonite 7 half length of 6 , also shorter than pleon. Latter completely fused, with no sign of individual pleonites. Pleotelson tapering to slightly concave apex bearing 3 pairs of setae; 2 large anterior statocysts present.

Antennular flagellum of 3 articles, terminal article minute, bearing 3 aesthetascs. Antennal flagellum of 4 minute compressed setose articles. Mandibular palp of 3 articles, terminal article bearing 3 distal fringed setae; incisor of 4 cusps; lamina dentata having 6 serrations; molar short, blunt. Maxilla with 8 distal hooked setae. Maxilliped with ovate terminal article set on distolateral margin of subterminal article, bearing 4 mesial setae; no endite visible. Pereopod 1 robust, carpus posterodistally broadly rounded; propodus inflated, palm faintly convex, with 4 simple setae; unguis half length of dactylus. Pereopod 2, carpus triangular, lacking free anterior margin; propodus rectangular, about 3 times longer than wide, with stout posterodistal dentate seta. Pereopod 6, carpus with short free anterior margin; propodus with stout posterodistal dentate seta. Pereopod 7 absent. Pleopod 1, exopod opercular, with about 9 distal widely spaced plumose marginal setae; endopod reduced to very short rounded lobe lacking setae. Uropodal exopod ovate, with about 9 distal plumose marginal setae; endopod ovate, longer than basal width, setose.

REMARKs: The genus Saurantbura contained, until now, the single species S. goldmanorum Poore \& Kensley, 1981, from Lizard Island on the Great Barrier Reef. The new species, with its broadly rounded rostrum, is very similar to $S$. goldmanorum but differs in three major features: the maxillipedal palp consists of two articles (one in $S$. goldmanorum) and apparently lacks an endite, and the pleopod 1 endopod is well developed in the Australian species but reduced to a small rounded lobe in the new species. Eyes could not be detected in $S$. rapanui, but given the small size of these animals it is possible that the eye pigment has been lost in the preservative, because $S$. goldmanorum has small but well-pigmented eyes.

ETYMology: The specific name is that of the type locality, Easter Island, in the language of the Rapanui people and is used as a noun in apposition. 


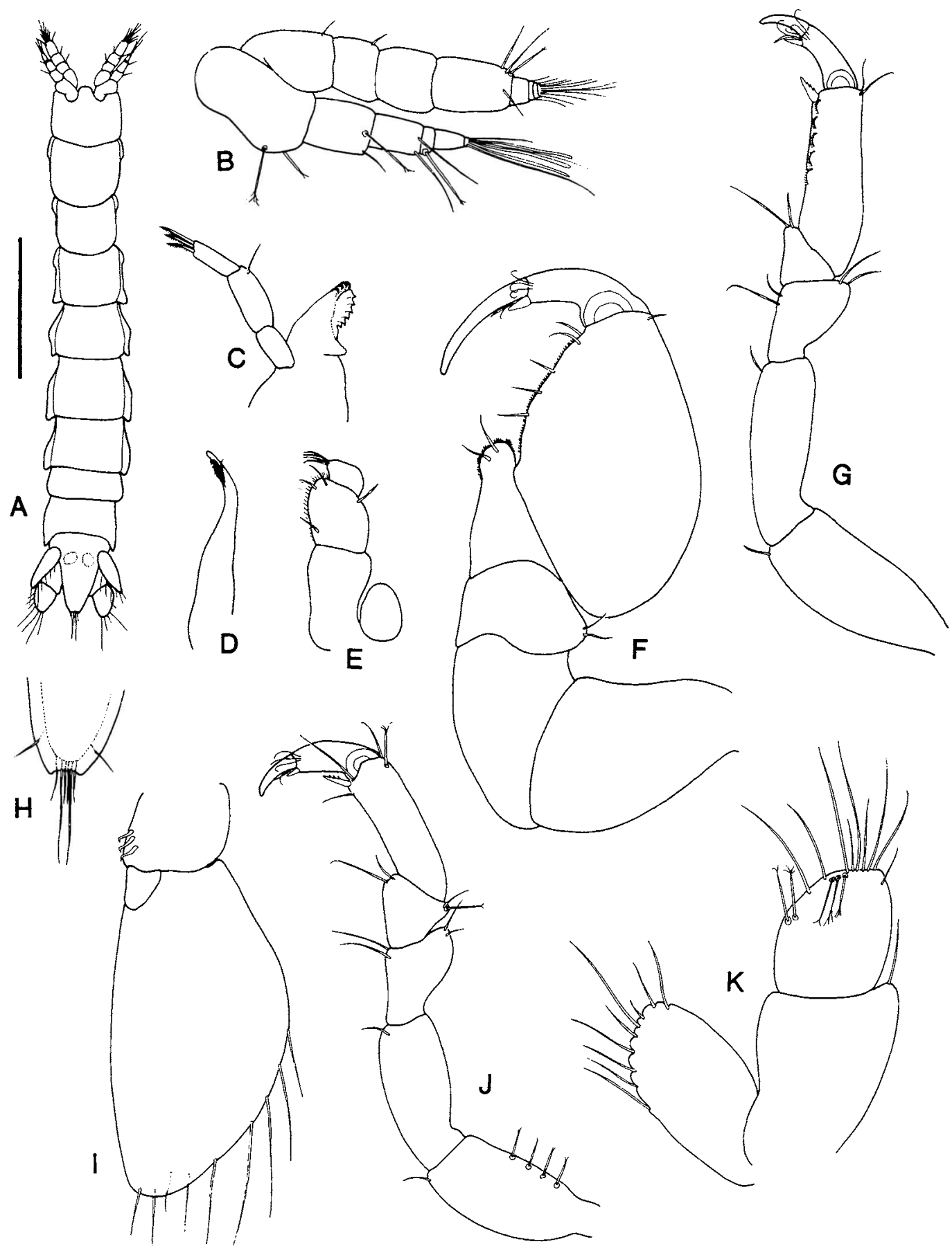

FIgURE 3. Saurantbura rapanui, n. sp. $A$, Nonovigerous $Q$ in dorsal view, scale $=0.5 \mathrm{~mm} ; B$, antennule and antenna; $C$, mandible; $D$, maxilla; $E$, maxilliped; $F$, pereopod $1 ; G$, pereopod $2 ; H$, apex of pleotelson; $I$, pleopod $1 ; 7$, pereopod 6 ; $K$, uropod. 
Family Expanathuridae

Genus Eisotbistos Haswell, 1884

\section{Eisotbistos sp.}

Material examined: 1 manca, Motu Iti, from Pocillopora coral, $52 \mathrm{~m}$, coll. H. Tonnemacher, 28 August 1999.

REMARKS: Because the single specimen is a manca, further identification is not possible.

\section{Genus Panathura Barnard, 1925}

\section{Panatbura sp.}

MATERIAL EXAMINED: 1 公, 1 immature $q$, Hanga Poukura, coll. A. Pianetti, 20 August 1998.

REMARKS: Because the male specimen is damaged and the female specimen is immature further identification is not possible.

\section{Family Paranthuridae}

Genus Califantbura Schultz, 1977

Califantbura dodecaseta Kensley, n. sp.

\section{Figure 4}

MATERIAL EXAMINED: Holotype: AMNH 18385, 1 o , $2.3 \mathrm{~mm}$, paratypes: AMNH 18386, 3 o , 2.2-2.3 mm; 2 nonovigerous +, $2.0 \mathrm{~mm}$; 3 juveniles, Motu Iti, $52 \mathrm{~m}$, from Pocillopora coral, coll. H. Tonnemacher, 28 August 1999. Paratypes: Usnm 1009135, 2 ð, 2.2, $2.3 \mathrm{~mm}$, Motu Iti, $52 \mathrm{~m}$, from Pocillopora coral, coll. H. Tonnemacher, 28 August 1999. Paratype: AMNH 18387, 1 ovigerous $9,2.7 \mathrm{~mm}$, Ahu Te Peu, $18 \mathrm{~m}$, coll. H. Tonnemacher, 29 August 1999.

DESCRIPTION: Cephalon slightly longer than wide, with short triangular rostrum, eyes in rounded anterolateral lobes. Pereonite 7 very short but having free lateral margins. Pleonites 1-5 fused, tiny lateral setae only sign of original pleonites, posterior margin of fused pleonites concave; pleonite 6 consisting of 2 broad lobes with narrow slit between. Telson about twice longer than wide, lacking statocyst; posterior margin evenly convex, bearing 5 pairs simple setae.

Antennular flagellum of 7 articles, 2-6 bearing clumps of elongate aethetascs. Antennal peduncle article 2 longest, article 3 shortest, articles 4 and 5 subequal; flagellum of single setose article. Pereopod 1, carpus triangular, with almost no free anterior mar- gin; propodus 1.7 times longer than broad, with broadly triangular basal thumb, row of 12 spinelike setae on mesial surface near thumb, palmar margin gently convex. Pereopods 2 and 3 , basis longest article; carpus triangular, lacking free anterior margin; propodus 2.5 times longer than wide, with 5 stout denticulate setae and set of fringed scales on posterior margin. Pereopods 4-6, carpus with single stout seta posterodistally, with anterior margin shorter than posterior; propodus about 3.3 times longer than wide, with row of scalelike setae on posterior margin, single stout denticulate seta posterodistally; pereopod 7 lacking. Pleopod 1, exopod opercular, about 2.3 times longer than wide, with 8 plumose marginal setae; endopod narrow, slender, about two-thirds length of exopod, with 2 distal setae. Pleopod 2, rami subequal in length and width, each with 3 distal plumose marginal setae; copulatory stylet articulating at base of endopod, reaching well beyond apex of ramus, with apical hook. Uropodal exopod ovate, with about 10 elongate simple setae on lateral margin; endopod semicircular, with numerous elongate simple setae on distal margin.

REMARKs: Poore (1984a) rediagnosed Califantbura, characterizing it chiefly by the very short pereonite 7 and the completely fused pleonites 1-5. Six species of Califanthura have been described. These are all morphologically very similar. The new material is characterized by the row of 12 setae on the mesial surface of the propodus of pereopod 1 , the five stout setae on the propodus of pereopods 2 and 3, and the slender endopod of pleopod 1 with its two distal setae. None of the previously described species has this combination of features. Only $C$. minuta Kensley \& Heard, 1991, at $1.6 \mathrm{~mm}$ total length, from the Turks and Caicos, is smaller than $C$. dodecaseta $(2.2-2.7 \mathrm{~mm})$; the five other species range in total length from 3.7 to $7.9 \mathrm{~mm}$.

ETYMOLOGY: The specific name refers to the row of 12 setae on the palm of pereopod 1 of the male.

Genus Paranthura Bate \& Westwood, 1868

Parantbura nordenstami Kensley, n. sp. Figure 5 


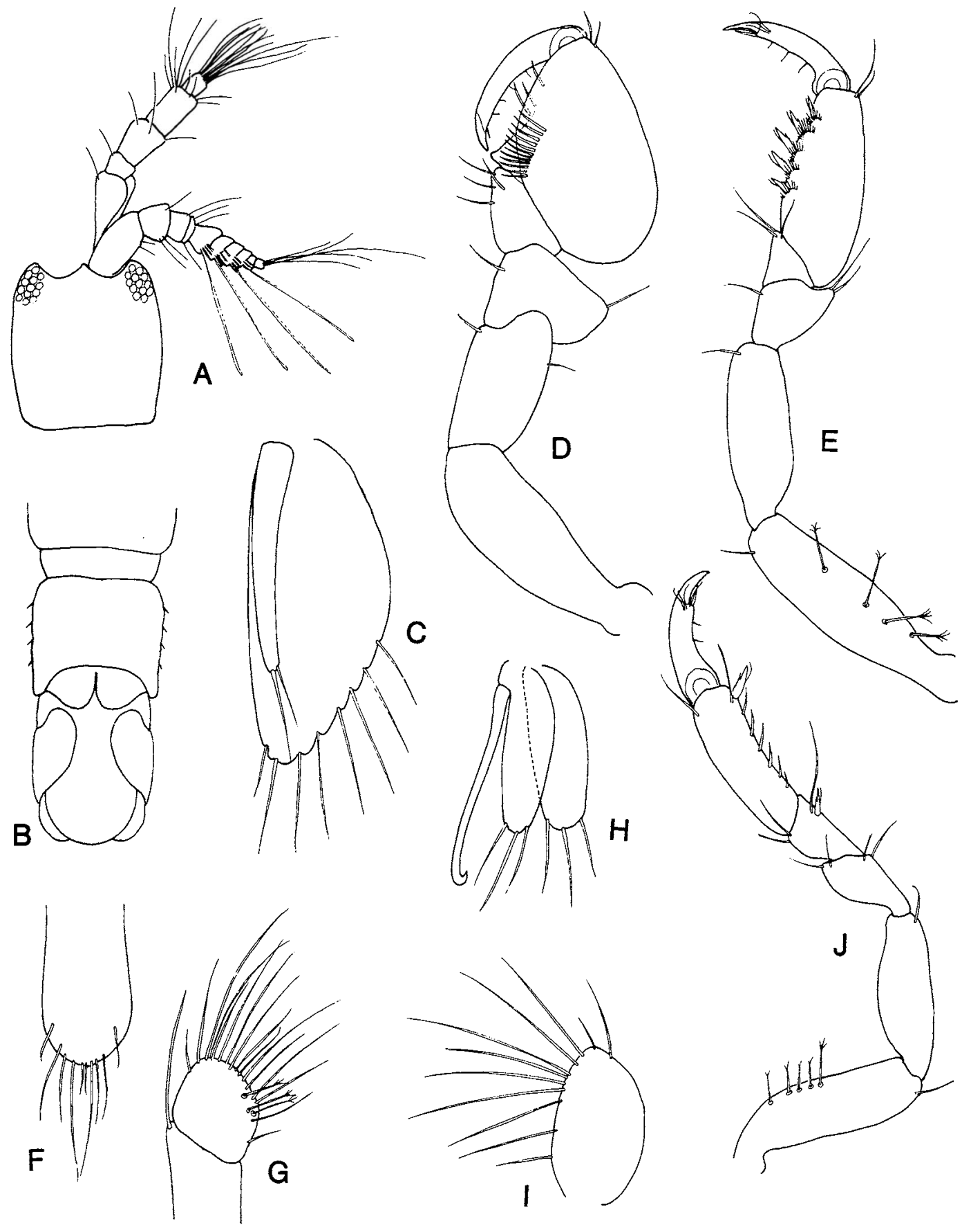

Figure 4. Califantbura dodecaseta, n. sp. $A$, o cephalon, antennule, and antenna; $B$, pleon and pleotelson; $C$, pleopod 1 ; $D$, pereopod $1 ; E$, pereopod $2 ; F$, pleotelson; $G$, uropodal endopod; $H$, pleopod $2 ; I$, uropodal exopod; 7 , pereopod 6 . 


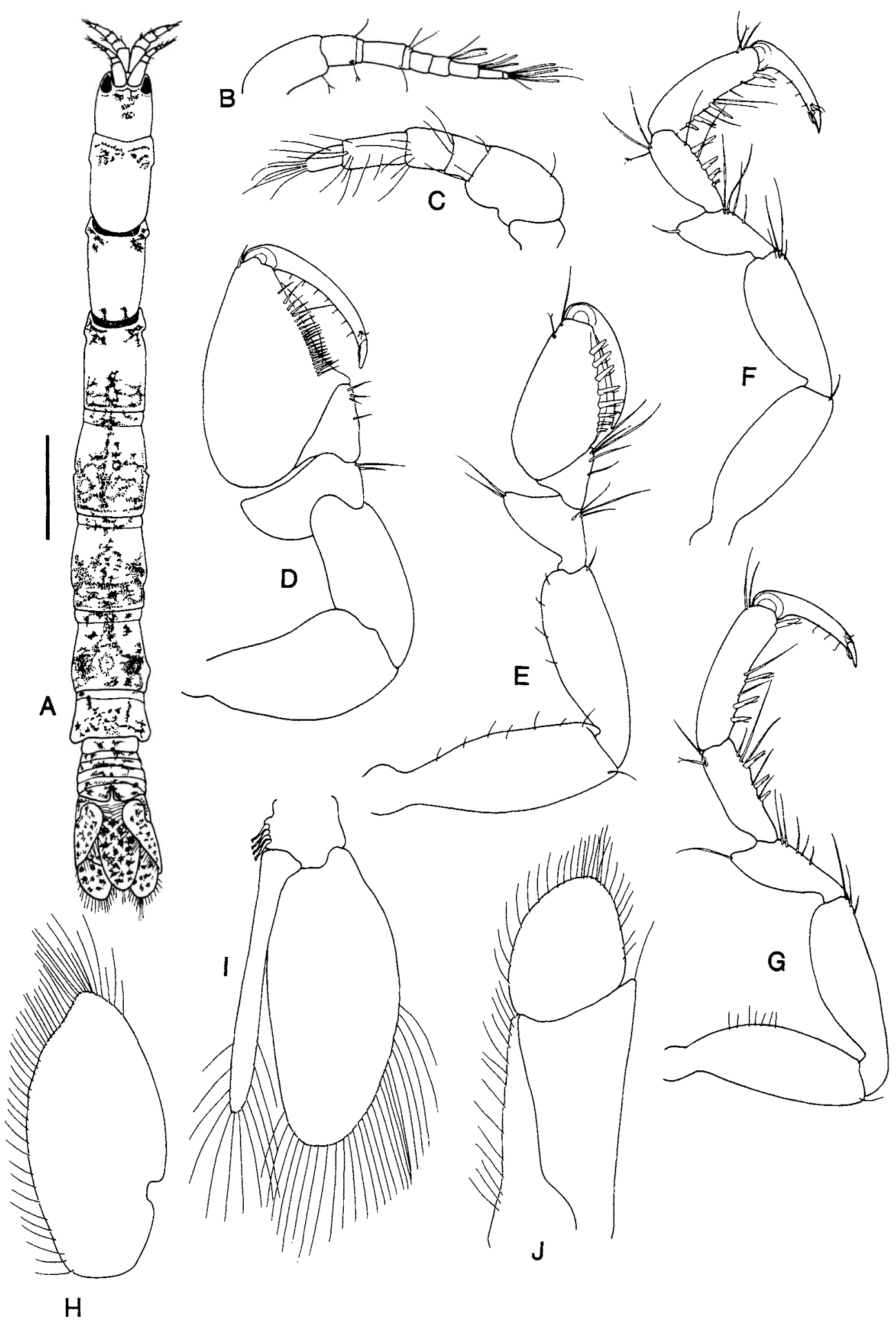


MATERIAL EXAMINED: Holotype: AMNH 18388, 1 nonovigerous $+9.9 \mathrm{~mm}$, paratype: AMNH 18389, 1 nonovigerous o, $4.5 \mathrm{~mm}$, Hanga Tee O Vaiha, Easter Island, coll. C. Boyko and J. Tancredi, 24 August 1999.

DESCRIPTION: Body with dorsolateral network of red brown pigment, denser in posterior pereon and pleon than in cephalon and anterior pereonites. Cephalon with rounded anterolateral lobes bearing well-pigmented eyes, reaching anteriorly well beyond rostral apex. Pereonites 4-7 each with impressed tranverse line close to anterior margin. Pereonite 7 subequal in length to pleonites, pleonite 1 twice length of 2 , pleonite 6 with middorsal slit. Telson linguiform, tapering posteriorly to rounded apex.

Antennular flagellum of 7 articles, basal article longest, with 3 terminal aesthetascs, 2 aesthetascs on penultimate and antepenultimate articles. Antennal flagellum of single setose article. Pereopod 1, carpus triangular, distally rounded; propodus inflated, with rounded proximal lobe of palm, latter with convex flange flanked by row of about 22 setae; dactylar unguis reaching propodal lobe. Pereopod 2, carpus triangular; propodus less inflated than in pereopod 1, with convex palmar flange and submarginal row of 8 stout sensory setae. Pereopods 4-7 similar, merus with triangular anterodistal lobe; carpus roughly rectangular, bearing 3 or 4 stout sensory setae on posterior margin; propodus rectangular, 3-4 times longer than wide, with 3 stout sensory setae in proximal half, single stout seta posterodistally. Pleopod 1, exopod opercular, slightly more than twice longer than greatest width, with about 26 plumose marginal setae in distal half; endopod slender, shorter than, and about one-sixth width of exopod, with 12 distal plumose marginal setae. Uropodal exopod twice longer than greatest width, margins setose, with slight sinuosity in distolateral margin, apex rounded; endopod ovate with marginal setae.
REMARKS: The nearest records of Paranthura to Easter Island are from Juan Fernández Island, about $3000 \mathrm{~km}$ away. Nordenstam (1930) described P. skottsbergi, $P$. gracilipes, and $P$. nana from that remote locality. Of these, $P$. nana has a more robust pereopod 1 with fewer propodal setae and a subspherical uropodal exopod. The new material, however, appears very similar to both $P$. skottsbergi and $P$. gracilipes, especially in shape of the pereopods and uropodal rami. The major differences lie in the second pereopod, which has fewer stout palmar setae (8) than in the Juan Fernández species (10); in the pleopod 1 endopod, which is relatively shorter in $P$. skottsbergi; and in the shape of the telson, which is more lanciform in $P$. nordenstami. Although these differences may seem slim, Poore (1984b:33) remarked on the subtle differences that separate the many species of Parantbura and that "Given the apparent richness of the Australian fauna it is probable that other areas also possess endemic cryptic species as yet undescribed."

ETYMOLOGY: The species is named for Ake Nordenstam, Norwegian biologist of the early twentieth century.

\section{Suborder Asellota \\ Family Gnathostenetrioididae \\ Genus Maresiella Fresi \& Scipione, 1980}

\section{Maresiella sp.}

MATERIAL EXAMINED: 1 ovigerous $q, \mathrm{Pu}-$ nakapi Point, Te Raha, coll. V. Killorin, 21 August 1998.

REMARKS: With only a single female available, further identification is not possible.

Family JaNiridae

Genus Carpias Richardson, 1902

\section{Carpias sp.}

MATERIAL EXAMINED: 1 ovigerous 9 , Hanga Poukura, coll. A Pianetti, 20 August 1998. 1 ovigerous $q$, Hanga Tee, coll. A. Pianetti, 20 August 1998. 1 ㅇ, Hanga Tee, coll. A. Pianetti, 20 August 1998. 2 O, Oroi

Figure 5. Parantbura nordenstami, n. sp. $A$, Holotype $\odot$ in dorsal view, scale $=1.0 \mathrm{~mm} ; B$, antennule; $C$, antenna; $D$, pereopod $1 ; E$, pereopod $2 ; F$, pereopod $4 ; G$, pereopod $7 ; H$, uropodal exopod; $I$, pleopod $1 ; \mathcal{F}$, uropodal endopod and basis. 
Point, coll. V. Killorin, 21 August 1998. 2 ovigerous 9 , Oroi Point, coll. J. Quillen, 21 August 1998. 1 ơ, 1 ㅇ, Punakapi Point, Te Raha, coll. V. Killorin, 21 August 1998. 1 \%, Ataranga Bay, sta. 9.5, coll. V. Killorin, 23 August 1998. 1 ovigerous 우, Hanga Tee O Vaihu, coll. C. Boyko and J. Tancredi, 24 August 1999.

REMARKS: Because there are only two males in this material, neither having the diagnostic first pereopods, further identification is not possible, although the species does resemble $C$. algicola (Miller, 1941).

Family JoeropsididaE

Genus foeropsis Koehler, 1885

Joeropsis acoloris Kensley, n. sp.

Figure 6

MATERIAL EXAMINED: Holotype: AMNH 18390, 1 of, $1.6 \mathrm{~mm}$, Akahanga, sta. 4.1, coll. A. Pianetti, 20 August 1998. Paratypes: AMNH 18391, sta. 5.3, Oroi Point, 1 \&, $2.0 \mathrm{~mm} ; 1$ juvenile, $1.5 \mathrm{~mm}$, coll. J. Quillen, 21 August 1998. AMNH 18392, 1 o, $1.0 \mathrm{~mm}$, Oroi Point, sta. 5.2, coll. J. S. Friedman, 21 August 1998. Paratype: USNM 1008955, sta. 9.3, Ataranga Bay, 1 ovigerous ㅇ, $2.0 \mathrm{~mm}$, coll. V. Killorin, 23 August 1998.

DESCRiption: Male: Rostrum ovate, broader basally than distally. Eye consisting of 7 ommatidia. Anterolateral corners of pereonites 1 and 2 subacute; pereonites 3-5 rounded; pereonites 6 and 7 slightly produced posterolaterally. Pleotelson slightly longer than wide, cordate; lateral margins unarmed, posterior margin rounded. Antennule with basal article broad, equal in length to following 3 articles; terminal article bearing 2 aesthetascs. Antenna with 3 basal articles short, narrow, article 4 longest and widest; flagellum of 5 or 6 tiny articles. Pleopod 1 in male elongate, rami fused for about three-fourths mesial length; distal margin of each ramus convex, bearing about 9 or 10 setae. Pleopod 2 protopod 2.5 times longer than wide; exopod short, stubby, rounded; endopod slender, tapered stylet reaching beyond apex of ramus. Uropodal protopod with strong hyaline hook distomesially; rami short, bearing elongate setae.

Body lacking pigment.
REMARKS: The new species bears little resemblance to any of the species of foeropsis described from the central South Pacific, especially in its lack of any pigment pattern.

ETYMOLOGY: The specific name, from the Latin for having no color, refers to the lack of a pigment pattern.

\section{Joeropsis bicomis Kensley, n. sp.}

Figure 7

MATERIAL EXAMINED: Holotype: AMNH 18393, 1 ovigerous , total length $2.2 \mathrm{~mm}$, paratype: AMNH 18394, 1 ㅇ, $2.0 \mathrm{~mm}$, Hanga Tee O Vaihu, coll. J. Tancredi, 24 August 1998. Paratype: UsNm 1008956, 1 아 $1.5 \mathrm{~mm}$, Moai tide pool near Tongariki, coll. C. Boyko, 25 August 1999.

DESCRIPTION: Female: Rostrum evenly convex. Anterolateral corners of pereonites 1-4 and posterolateral corners of pereonites 5-7 rounded. Body widest at pereonite 3 . Pleotelson greatest width slightly more than middorsal length, lateral margin having 2 small teeth. Antennule basal article with rounded distolateral lobe; 3 distal articles subequal in length, terminal article bearing 2 aesthetascs. Antenna flagellum of 5 tiny setose articles. Uropodal rami short, rounded, setose; distal lobe of protopod rounded, lacking hook or spine.

Body with strong dark brown pigment on anterior head and around eyes with triangular extensions into lateral base of rostrum and into anterolateral angle of head; pigment forming less dense reticulate pattern on all pereonites and pleotelson.

REMARKs: Foeropsis bicornis bears some resemblance to 7 . salvati Müller, 1989, from Moorea in the Society Islands, especially in the color pattern, but several differences separate these two species: the pigment patch on the cephalon in 7. bicornis has two distinct anterior "horns," not seen in 7 . salvati; the latter has five teeth on the lateral margins of the pleotelson, but there are only two in $\mathcal{F}$. bicornis; the long fourth article of the antenna has several serrations on the mesial margin in 7. salvati but is entire in $\mathcal{7}$. bicornis.

ETYMOLOGY: The specific name, bicomis, meaning two horns, refers to the pigment pattern seen on the cephalon. 

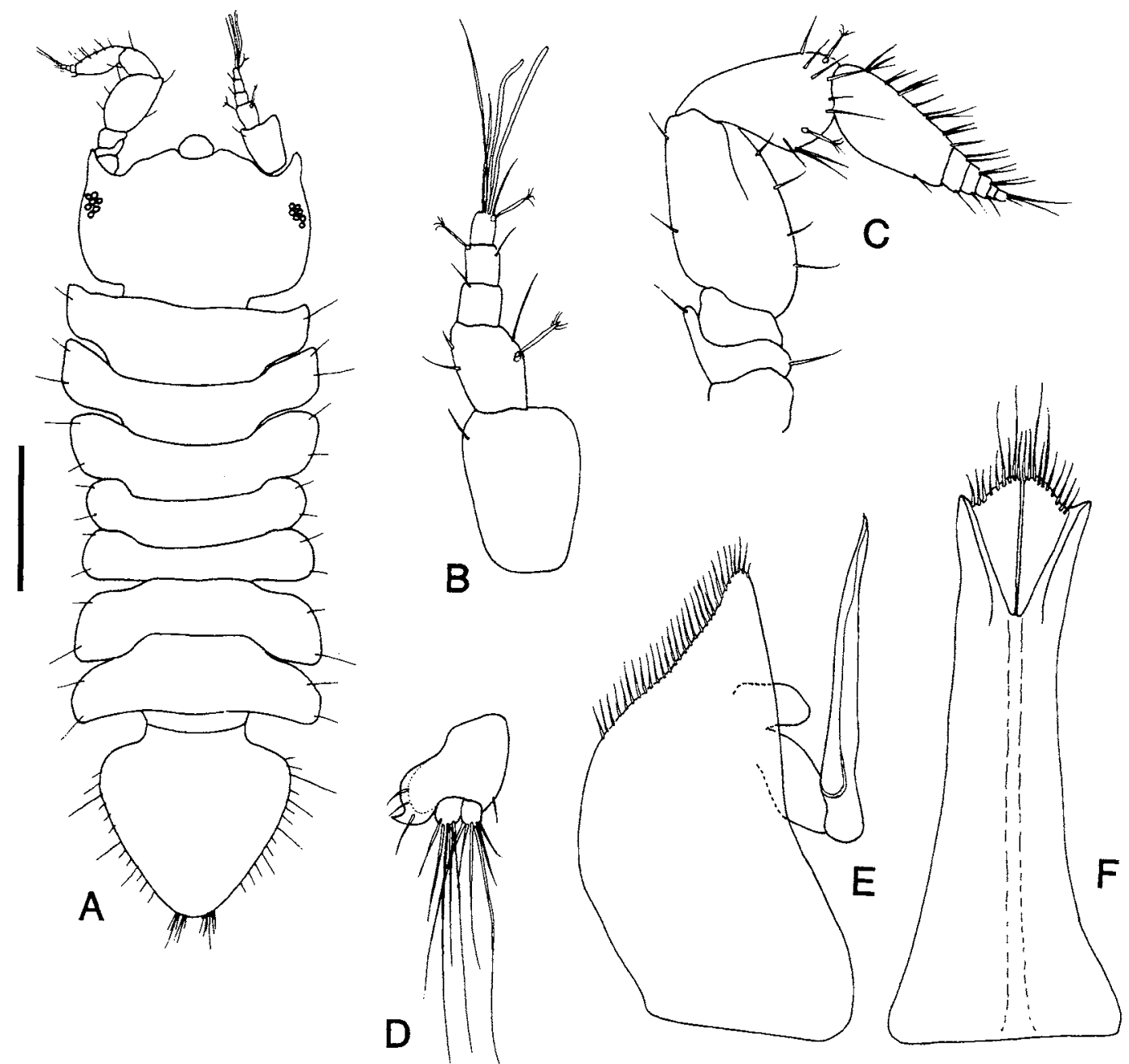

Figure 6. Foeropsis acoloris, n. sp. $A, \delta$ in dorsal view, scale $=0.3 \mathrm{~mm} ; B$, antennule; $C$, antenna; $D$, uropod; $E$, pleopod $2 ; F$, pleopod 1 .

Joeropsis limbatus Kensley, n. sp.

\section{Figure 8}

MATERIAL EXAMINED: Holotype: AMNH 18395,1 ㅇ, $1.9 \mathrm{~mm}$, paratype: АMNH 18396, 1 đ, $1.6 \mathrm{~mm}$, Motu Iti, from Pocillopora coral, $52 \mathrm{~m}$, coll. H. Tonnemacher, 28 August 1999. Paratypes: USNM 1008957, 2 ot, $1.1 \mathrm{~mm}$, 1.4 ( $\mathrm{mm}$ dissected on slide), Tongariki, coll. C. Boyko and J. Tancredi, 22 August 1999.

DESCRIPTION: Male: Body highly flattened, about 1.7 times longer than greatest width at pereonite 5; cephalon, pereonites, and pleon having broad transparent margins, numerous scattered short setae on dorsum, lacking pigmentation. Cephalon narrower than pereonite 1, with broad rostrum anteriorly slightly concave; anterolateral angles rounded; dorsolateral eye with 19-20 ommatidia. Pereonites middorsally subequal in length, 1-4 laterally truncate with rounded corners; pereonites 5-7 laterally truncate, slightly produced posterolaterally. Pleon consisting of single anterior pleonite lacking 

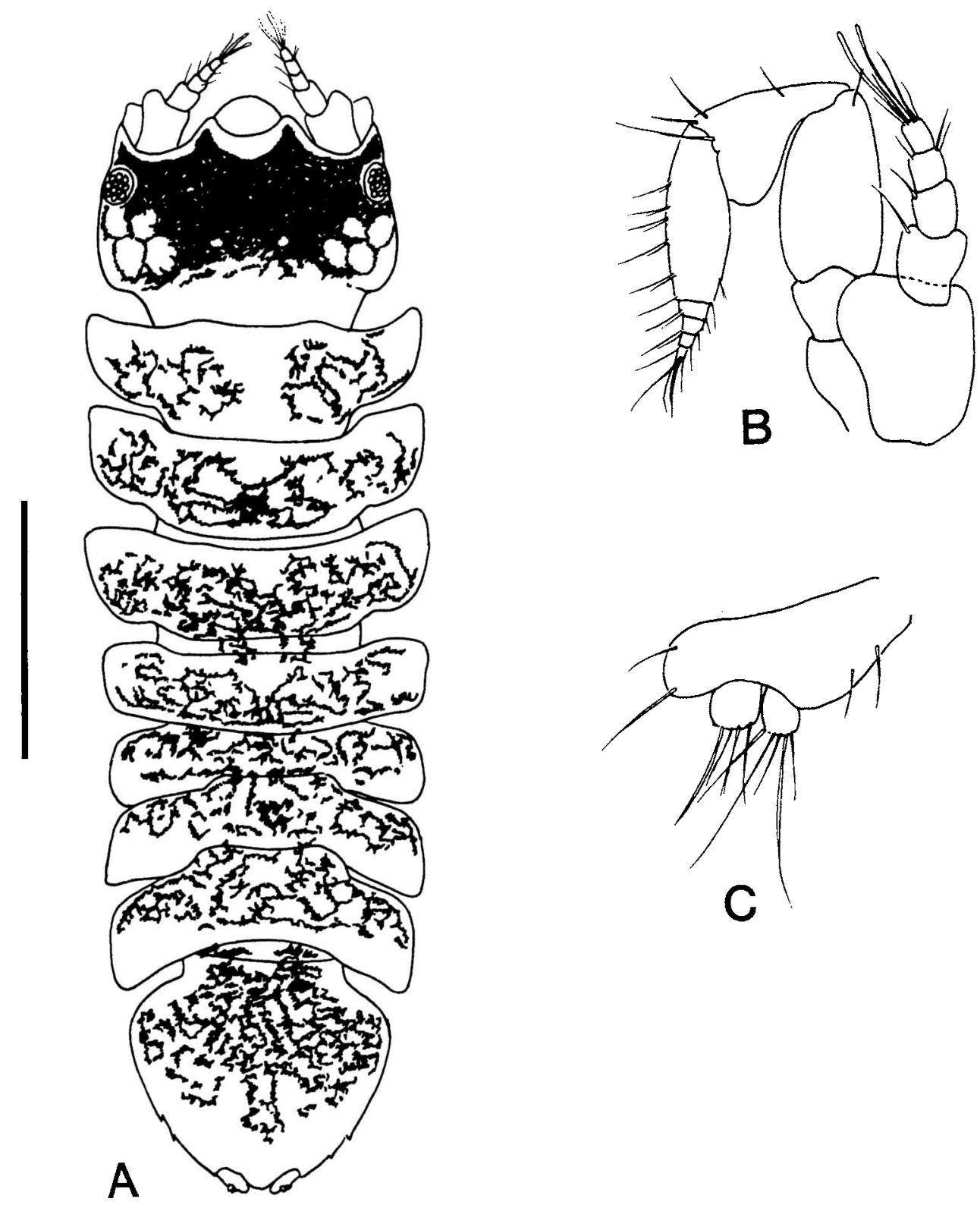

Figure 7. Foeropsis bicornis, n. sp. $A$, Ovigerous $q$ in dorsal view, scale $=0.5 \mathrm{~mm} ; B$, antennule and antenna; $C$, uropod.

free lateral margins, plus pleotelson. Latter almost twice wider than midlength, lateral margins slightly convex, posterior margin between uropods narrowly triangular.

Antennule of 6 articles, basal article longest and widest; terminal article very short, bearing 2 aesthetascs. Antenna with 3 basal articles short, article 4 largest, 1.6 times longer than greatest width, with broad convex transparent flange on lateral margin; article 5 


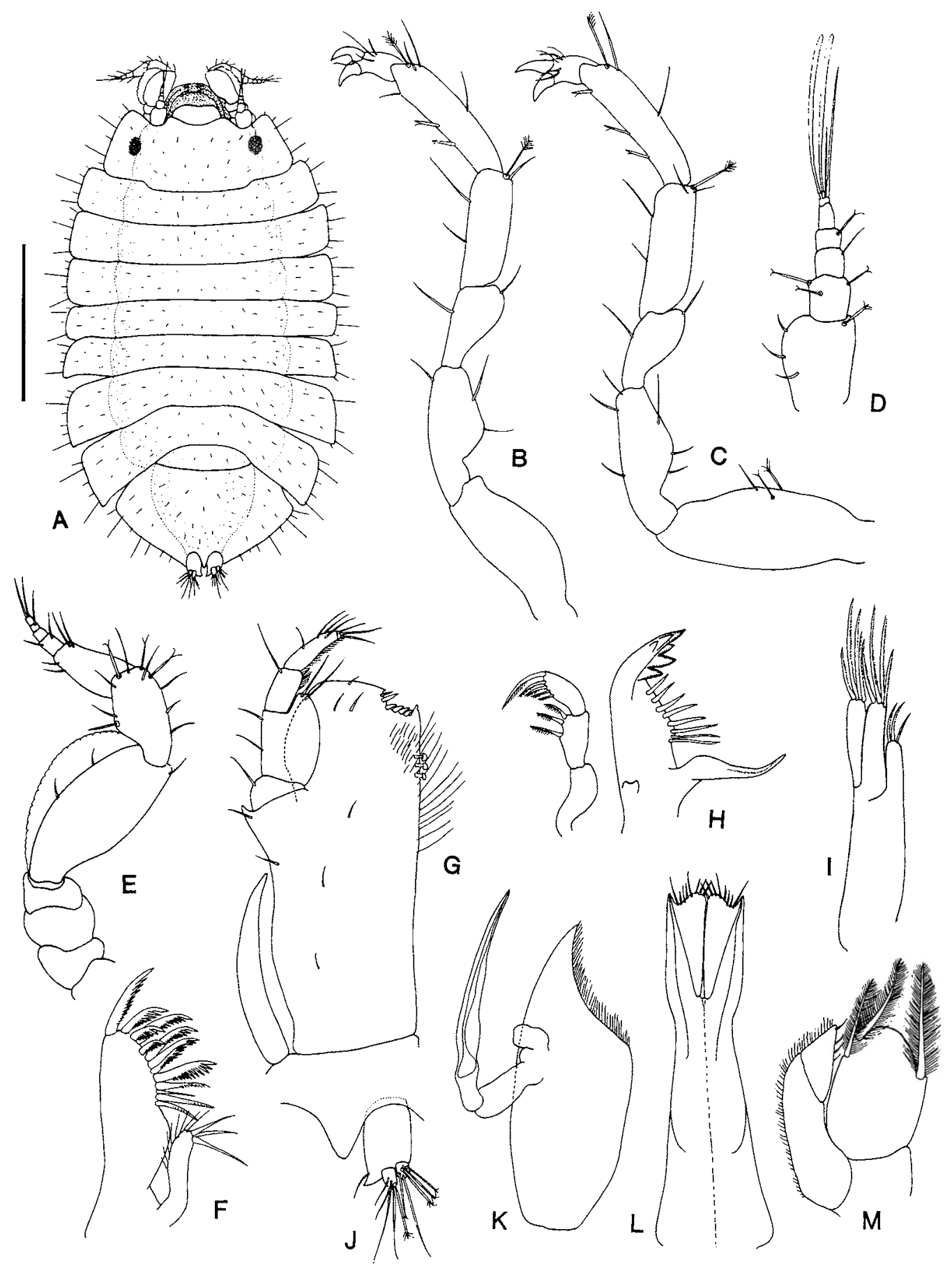

Figure 8. Foeropsis limbatus, n. sp. A, Holotype $q$ in dorsal view, scale $=0.5 \mathrm{~mm} B$, pereopod $1 ; C$, pereopod 7; $D$, antennule; $E$, antenna; $F$, maxilla $1 ; G$, maxilliped; $H$, mandible and palp; $I$, maxilla $2 ; \mathcal{F}$, uropod; $K$, pleopod $2 \delta, L$, pleopod 1 ; $M$, pleopod 3. 
0.6 times length of 4 , much narrower, bearing several simple and bottlebrush setae; flagellum of 5 articles, basal article longer than remaining articles. Mandibular palp of 3 articles, article 2 with 3 pectinate setae in distal half; article 3 curved, with 5 pectinate setae in distal half, increasing in length distally; incisor process of 6 acute cusps; 8 well-separated setae in setal row; molar elongate tapering, apically acute. Maxilla 1 , inner ramus with 3 simple, basally stout distal setae; outer ramus with 13 strong dentate setae. Maxilla 2, 2 outer lobes bearing 4 elongate pectinate setae distally; mesial lobe shorter than lateral lobes, bearing 3 pectinate setae distally. Maxillipedal palp of 5 articles, basal article short, article 2 longest with broad rounded lobe on mesial margin; articles 3 and 4 narrow, subequal in length; article 5 minute, setose; endite broad, about twice longer than wide, 2 or 3 coupling hooks on mesial margin; distal margin rounded, excavate mesiodistally, emargination bearing 6 short setae; exite narrow, curved, not reaching basal palp article. Pereopods 1-7 similar, increasing slightly in length posteriorly; propodi rectangular, about 4 times longer than wide, with 2 or 3 sensory setae on posterior margin; dactylus biunguiculate, ungui subequal, stout. Pleopod 1 elongate, narrow, rami fused for about 0.3 times total length, distal margin mesially rounded, with 8 setae, distolateral corner produced into triangular spout. Pleopod 2, protopod distally narrowly acute, distolateral margin concave, setose; endopod distal article elongate slender, tapering, reaching beyond protopod distally. Pleopod 3, endopod of single broad article bearing 3 large distal feather setae; exopod of elongate basal article and smaller triangular distal article; lateral margins fine setose. Uropodal protopod longer than wide, with triangular hook mesiodistally; endopod longer than exopod bearing several elongate simple setae; exopod bearing 4 or 5 elongate bottlebrush setae.

REMARKS: Just (2001), in describing two new genera in the Joeropsididae, suggested that further genera may be differentiated from the host of described foeropsis species. The new species, with its broadly ovate body outline and highly flattened build, bears little resemblance to any previously described species and might be such a candidate.

ETYMOLOGY: The specific name is from the Latin limbatus, meaning bordered, and refers to the broad lateral flange seen on the cephalon, pereon, and pleon.

\section{Foeropsis trilabes Kensley, n. sp.}

Figure 9

MATERIAL EXAMINED: Holotype: AMNH 18397,1 శో, $1.3 \mathrm{~mm}$, paratypes: AMNH 18398 , 1 oै, $1.2 \mathrm{~mm}$ (dissected); 1 O, $1.2 \mathrm{~mm}$; 1 juvenile, Piko, coll. C. Boyko and S. Reanier, 31 August 1999. 1 juvenile, Moai tide pool, 25 August 1998. Paratypes: usnm 1008958, 2 juveniles, $1.0 \mathrm{~mm}, 0.9 \mathrm{~mm}$, Tongariki, Moai tide pool, coll. C. Boyko, 22 August 1999.

DESCRIPTION: Rostrum subcircular, with anterior margin faintly concave mesially. Anterolateral corners of pereonites 1-4 and posterolateral corners of pereonites 5-7 rounded. Body widest at pereonites 5 and 6 . Pleotelson as long as wide, narrowed posteriorly to broadly rounded apex; margins unarmed. Antennule with basal article almost as long as 5 remaining articles; terminal and penultimate articles each with single aesthetasc. Antenna with article 5 of peduncle basally broad, tapering distally, with dense elongate setae on posterior half of article; flagellum of 6 tiny articles. Pleopod 1 in male elongate, rami fused for about three-fourths mesial length; distal margin of each ramus convex, bearing about 10 marginal setae. Pleopod 2 protopod almost 3 times longer than wide; exopod short, stubby, triangular; endopod distally tapered to stylet just reaching beyond apex of ramus. Uropodal protopod with strong hyaline hook distomesially; rami short, bearing elongate setae.

Body with strong dark brown pigment on head between eyes, with roughly convex margin short of anterior margin of head; strong patch of pigment in middorsal region of pereonite 3 and wider area on pereonite 4; strong patch of pigment on pleotelson, with reticulation on pereonites 1 and 2, 6 and 7 . Pereonite 5 free of pigment.

REMARKs: The new species, with its distally truncate rostrum, broadly rounded posterior margin of the pleotelson, the latter 


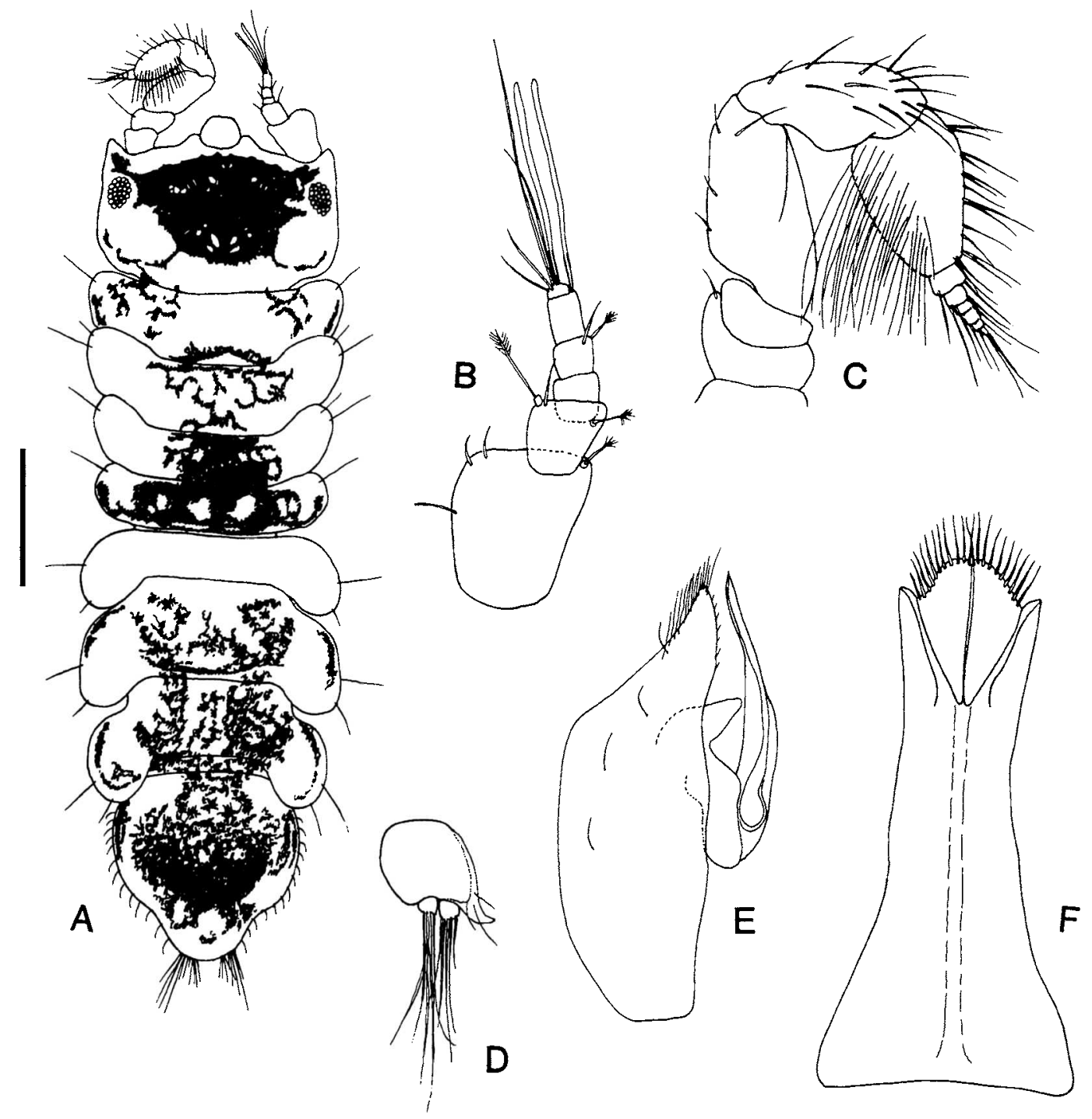

Figure 9. Foeropsis trilabes, n. sp. $A$, Paratype $\delta$ in dorsal view, scale $=0.3 \mathrm{~mm} ; B$, antennule; $C$, antenna; $D$, uropod; $E$, pleopod $2 ; F$, pleopod 1 .

lacking lateral teeth and uropodal emarginations, the rounded lateral regions of pereonites 5-7, and the tripartite color pattern, bears little resemblance to any previously described species. The numerous elongate setae on the sixth article of the antennal peduncle also seem to be a distinctive character of this species.

ETYMOLOGY: The specific name, from the Latin tri-, meaning three, and labes, a blot or stain, refers to the tripartite color pattern on the dorsum of the species.

\section{Family MunNidae}

Genus Munna Kröyer, 1839

Munna sp.

MATERIAL EXAMINED: 10 specimens, Motu Iti, from Pocillopora coral, $52 \mathrm{~m}$, coll. H. Tonnemacher, 28 August 1999.

REMARKS: Because most of the specimens 


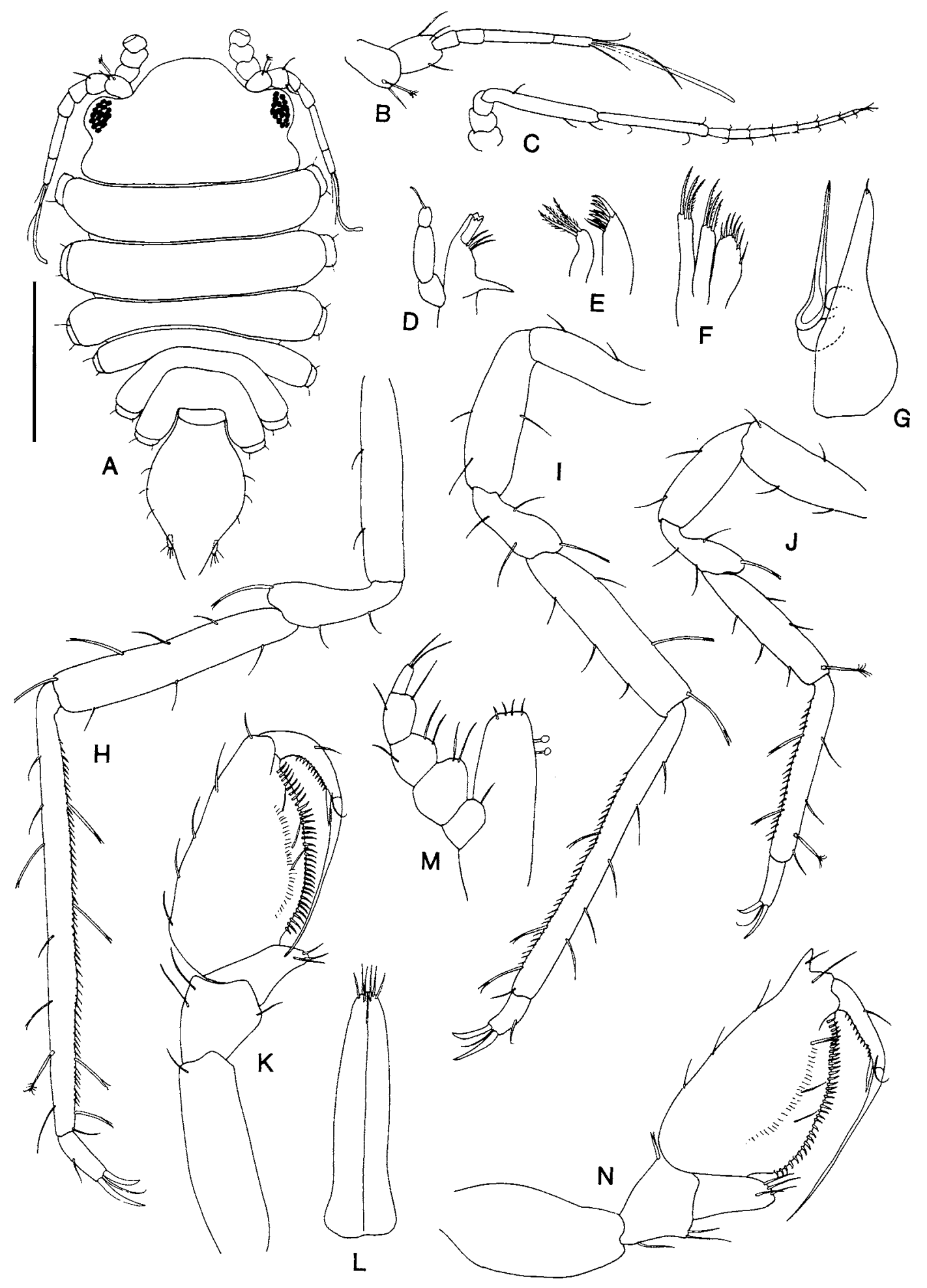


lack pereopods, including the first pereopods of the male, further identification is not possible.

\section{Genus Salvatiella Müller, 1990}

Salvatiella islapascua Kensley, n. sp.

Figure 10

MATERIAL EXAMINED: Holotype: AMNH 18399,1 ovigerous + , $0.5 \mathrm{~mm}$, paratypes: AMNH 18400, 1 ovigerous , $0.4 \mathrm{~mm}$; 3 juveniles, Motu Iti, from Pocillopora coral, $52 \mathrm{~m}$, coll. H. Tonnemacher, 28 August 1999. Paratypes: USNM 1008959, 1 đo $0.5 \mathrm{~mm}$; 1 ovigerous 우, $0.5 \mathrm{~mm}$ (dissected on slide), Motu Iti, from Pocillopora coral, $52 \mathrm{~m}$, coll. H. Tonnemacher, 28 August 1999.

DESCRIPTION: Male: Body widest at pereonite 3. Cephalon 1.8 times wider than middorsal length, with frontal margin evenly convex. Pereonite 1 completely fused with cephalon; coxa not visible in dorsal view, large muscle mass of pereopod 1 dorsally visible just posterior of eye. Coxae visible on pereonites 2-7. Pleon 1.8-1.9 times longer than wide, with single pleonite anteriorly, lacking free lateral margins. Pleotelson widest at about midlength, posterior margin between uropods tapering to narrowly rounded apex. Eye on short lateral lobe, having 20 ommatidia.

Antennule having 2 subequal broad basal articles, followed by 2 short subequal narrower articles, plus 2 more elongate cylindrical articles, terminal article bearing single terminal aesthetasc. Antenna having 4 short basal articles, followed by two elongatecylindrical articles; flagellum of 8 articles, terminal article tiny. Mandibular palp of 3 articles, article 22.5 times longer than terminal article; latter bearing single seta; setal row with 3 or 4 setae; molar slender, tapering, apically acute. Maxillipedal palp of 5 articles, article 2 longest and broadest; endite distally truncate, bearing few setae; 2 coupling hooks on mesial margin. Pereopod 1, ischium elon- gate-cylindrical, 2 to 3 times longer than wide; merus half length of ischium, about as wide as long, widening distally; carpus lacking free anterior margin, posterodistally forming a rounded lobe bearing few setae; propodus about 1.7 times longer than wide, widest proximally, with anterodistal spike, palm gently convex, bearing row of about 34 short curved spinelike setae; dactylus elongate, slender, reaching to carpal lobe, with row of about 12 very short setae on inner margin, unguis elongate, slender, longer than basal part of dactylus, with accessory seta. Pereopods 2 to 7 essentially similar, becoming longer posteriorly. Pereopod 2, merus with rounded anterodistal lobe bearing sensory seta; carpus rectilinear, 4 times longer than wide; propodus slender, rectilinear, about 7.5 times longer than wide, with 2 sensory setae on posterior margin plus row of very short fine setae; dactylus with strong accessory seta. Pereopod 4, propodus 13 times longer than wide, with 3 sensory setae on posterior margin. Pereopod 7, 17 times longer than wide, with 4 sensory setae on posterior margin. Pleopod 1, rami elongate, slender, apically rounded, bearing 3 setae. Pleopod 2, protopod distal half slender, tapering, apically subacute; stylet slender, tapering, acute, reaching distally to level of protopod apex. Uropod consisting of single ramus bearing few setae.

Female: Body considerably broader than in male. Pereopod 1 propodus lacking anterodistal spike. Antennae, mouthparts, and pereopods similar to those of male.

remarks: The genus Salvatiella Müller, 1990, was erected for S. polynesica Müller, 1990, described from two male specimens collected in $0.5-1 \mathrm{~m}$ in dead coral in the fringing reef of Bora Bora, French Polynesia. With both males and ovigerous females now available, the generic diagnosis can be emended: Pereonite 1 fused with cephalon, lacking free lateral margin. Mandibular molar slender, tapering; palp of 3 articles. Pereopod

Figure 10. Salvatiella islapascua, n. sp. $A$, Ovigerous $o$ in dorsal view, scale $=0.2 \mathrm{~mm} ; B$, antennule; $C$, antenna; $D$, mandible; $E$, maxilla $1 ; F$, maxilla $2 ; G$, pleopod $2 \delta ; H$, pereopod $7 ; I$, pereopod $4 ; 7$, pereopod $2 ; K$, pereopod $1 ; L$, pleopod $1 \AA ; M$, maxilliped; $N$, pereopod 1 . 


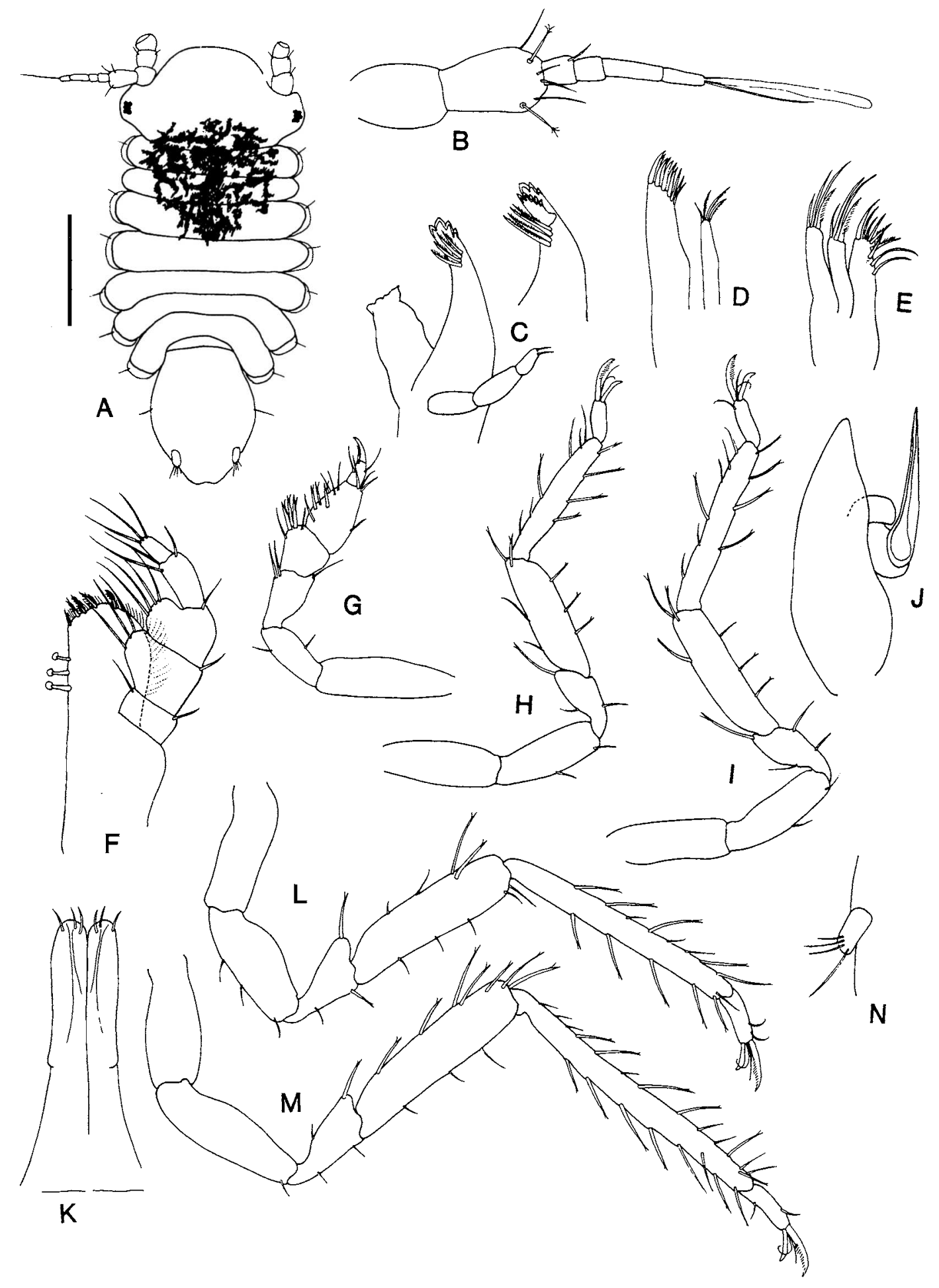


1 similar in male and female, except for distal propodal spike in male; robust, subchelate, shorter than following pereopods, with row of short spinelike setae along entire length of propodal palm, dactylus elongate, slender. Uropod of single ramus.

Although S. polynesica and the new material are morphologically very similar, a few subtle differences suggest that the Easter Island specimens are indeed a separate species, especially because about $4000 \mathrm{~km}$ separates the two sites: the pleon of $S$. islapascua, at 1.9 times longer than wide, is relatively more slender than that of $S$. polynesica (1.5 times); the distal spike on the propodus of the male pereopod 1 of $S$. polynesica is longer and set at a less acute angle than that of $S$. islapascua; pereonite 1 is shown in Müller's fig. 29 as being clearly demarcated from the cephalon, but in the new species there is no sign of a suture line between the two.

ETYMology: The specific name is the Spanish for Easter Island.

\section{Genus Uromunna Menzies, 1962}

Uromunna biloba Kensley, n. sp.

\section{Figure 11}

MATERIAL EXAMINED: Holotype: AMNH 18401, 1 o $0.8 \mathrm{~mm}$, paratypes: AMNH 18402, 13 o, $0.6-0.8 \mathrm{~mm} ; 7$ ovigerous +, $0.8 \mathrm{~mm}$ (7 eggs in brood pouch), 7 ; 4 juveniles, Hanga Tee O Vaihu, coll. C. Boyko and J. Tancredi, 24 August 1999. Paratypes: USNM 1008960, 2 o, $0.8 \mathrm{~mm} ; 2$ ovigerous $ᄋ, 0.8 \mathrm{~mm}$, Hanga Tee O Vaihu, coll. C. Boyko and J. Tancredi, 24 August 1999. Amn 18403, Hanga Poukura, sta. 2.2, 1 o, $0.7 \mathrm{~mm}$, coll. A. Pianetti, 20 August 1998. AMNH 18404, Tongariki, 2 ovigerous $+, 0.8 \mathrm{~mm}, 0.9 \mathrm{~mm}, 22$ August 1999. AMNH 18405, Moai tide pool near Tongariki, 1 ^, $0.8 \mathrm{~mm} ; 2$; 2 juveniles, coll. C. Boyko, 25 August 1999. AMNH 18406, Piko, 1 q, $0.6 \mathrm{~mm}$, coll. C. Boyko and S. Reanier, 31 August 1999.

Descriptron: Male: Body about twice longer than greatest width at pereonite 5 .
Cephalon about one-fourth total body length; pleotelson about one-third. Cephalon with broad lateral lobe bearing eye, latter of about 6 or 7 ommatidia, frontal margin broadly convex. Coxa visible laterally on pereonites. Pleotelson ovate, widest at about midlength, posterior margin gently bilobed.

Antennule consisting of 2 broad basal articles, 4 shorter and narrower distal articles, terminal article two-thirds length of penultimate article, bearing single aesthetasc. Mandibular palp of 3 articles, not reaching distally to incisor, terminal article with 2 short setae; setal row of 4 stout fringed setae; lacinia having 5 cusps; incisor of 3 or 4 cusps. Maxilla 1 inner ramus having 4 distal fringed setae; outer ramus with about 10 stout spinelike setae. Maxilla 2, inner ramus with 9 setae along mesial and distal margin; two outer lobes each bearing 4 fringed setae distally. Maxillipedal endite with 3 retinaculae on mesial margin, distal margin broadly convex, bearing 5 fringed setae and numerous fine simple setules; palp of 5 articles, articles 2 and 3 broadest, each with 3 or 4 setae on convex mesial margin, articles 4 and 5 narrower, with few simple setae. Pereopod 1 about half length of following pereopod; carpus roughly triangular, with 3 stout sensory setae posterodistally; propodus basally wide, tapering distally, with several sensory and simple setae on palmar margin; dactylus more than half length of propodus, unguis stout, half length of dactylus. Pereopods 2-4 similar, increasing in length posteriorly, merus half length of carpus, widening distally, bearing strong sensory setae on anterodistal lobe; carpus rectilinear, about 4 times longer than wide, with 3 sensory setae on posterior margin, 3 anterodistally; propodus rectilinear, narrower than carpus, about 5 to 7 times longer than wide, with 4 sensory setae on posterior margin, several sensory and simple setae on anterior margin; dactylus having robust pectinate seta, bladelike shorter accessory seta, and few fine setules distally. Pereopods 5-7

Figure 11. Uromumna biloba, n. sp. $A$, Paratype $\delta$, scale $=0.2 \mathrm{~mm} B$, antennule; $C$, left and right mandible; $D$, maxilla $1 ; E$, maxilla $2 ; F$, maxilliped; $G$, pereopod $1 ; H$, pereopod $2 ; I$, pereopod $3 ; \mathcal{Z}$, pleopod $2 ; K$, pleopod $1 ; L$, pereopod 5 ; $M$, pereopod $7 ; N$, uropod. 
similar, becoming longer posteriorly; merus widening distally, with sensory seta on anterodistal lobe; carpus rectilinear, about 4 to 4.5 times longer than wide, with several elongate sensory setae on anterior and distal margin, few simple setae on posterior margin; propodus elongate rectilinear, about 10 times longer than wide, with several sensory setae on anterior and posterior margins; dactylus as in earlier pereopods. Pleopod 1 , rami elongate, distally rounded, with 3 short setae. Pleopod 2 protopod tapering distally to narrowly rounded apex, about 2.5 times longer than wide; stylet tapering, narrow, reaching beyond apex of ramus. Uropod with large ramus bearing 4 distal setae; smaller ramus, if present, undetected.

Dark pigment patch dorsally on posterior cephalon and pereonites 1-3.

Female: Essentially similar to male, especially in pereopods.

REMARKS: 'The species of Uromunna all seem to have very similar external morphology; differences in appendages are subtle and uncertain, given the quality of the illustrations from earlier descriptions. Two species of Uromunna have been described from the Pacific Ocean: U. acarina (Miller, 1941) from Hawai'i and $U$. schauinslandi (Sars, 1905) from New Zealand (see Poore 1984c:81). The new species, although superficially very similar to $U$. acarina, possesses a bilobed pleotelsonic apex; the Hawaiian species has an evenly rounded apex. The New Zealand species, from Sars' illustrations (1905: pl. 14), has a truncate pleotelsonic apex, the rami of pleopod 1 in the male distally rounded but somewhat laterally flexed, and the stylet of pleopod 2 in the male not reaching beyond the apex of the ramus. Uromunna nana (Nordenstam, 1933) from the Falkland Islands has a rounded pleotelsonic apex, and the rami of pleopod 1 in the male are oblique-truncate, not rounded.

ETyMology: The specific name, meaning two lobes, refers to the faintly bilobed apex of the pleotelson.

\section{Family Paramunnidae}

Genus Paramunna Sars, 1866

Paramunna pellucida Kensley, n. sp.

Figure 12
MATERIAL EXAMINED: Holotype: AMNH 18407, 1 ovigerous +, $0.5 \mathrm{~mm}$, paratypes: AMNH 18408, 4 ovigerous $q$ (1 dissected on slide; 1-4 eggs in marsupium), 1 ㅇ, Motu Iti, from Pocillopora coral, $52 \mathrm{~m}$, coll. $\mathrm{H}$. Tonnemacher, 28 August 1999.

DESCRIPTION: Ovigerous female: Body 1.6 times longer than greatest width at pereonite 3. Cephalon middorsal length subequal to pereonites 1-3; anterior margin evenly convex; 4 ommatidia in eye situated on short lateral stalk. Pereonites and anterior part of pleotelson with transparent flange. Anterolateral corner of pereonites 1-3 narrowly rounded to subquadrate; pereonites 4-7 rounded. Pleotelson slightly wider than long, transparent flange entire, ending in narrow point at uropod; posterior margin evenly convex.

Antennule with 2 basal articles broadest, subequal, 4 distal articles narrower, terminal and subterminal articles subequal, with single distal aesthetasc. Antennal basal article short, article 24 times longer, article 3 short, articles 4 and 5 more elongate, article 5 longer; flagellum of 7 articles. Mandibular palp of 3 articles, article 2 longest; single distal seta on terminal article; molar subcylindrical, distally truncate with single seta; lacinia having 4 cusps; spine row with 4 stout setae; incisor of 4 cusps. Maxilla 1, inner ramus with 4 distal setae; outer ramus with about 8 distal spinelike setae. Maxilla 2, inner ramus with 8 setae on mesial and distal margins; both lobes of outer ramus with 4 elongate setae. Maxillipedal endite distally truncate, with 5 setae, mesial margin with 3 retinaculae; palp of 5 articles, articles 2 and 3 broadest. Pereopod 1 shorter but more robust than following legs; carpus roughly triangular, with 3 stout sensory setae posterodistally; propodus curved, palmar margin convex; dactylus shorter than anterior margin of propodus, unguis strong, about 0.7 times length of rest of article. Pereopods 2-7 similar, becoming longer posteriorly; merus with rounded anterodistal lobe; carpus and propodus cylindrical, bearing few setae; dactylus with strong unguis and slightly shorter stout accessory claw. Uropod consisting of 2 rami, one shorter and narrower with single terminal seta, longer with 3 or 4 distal setae. 


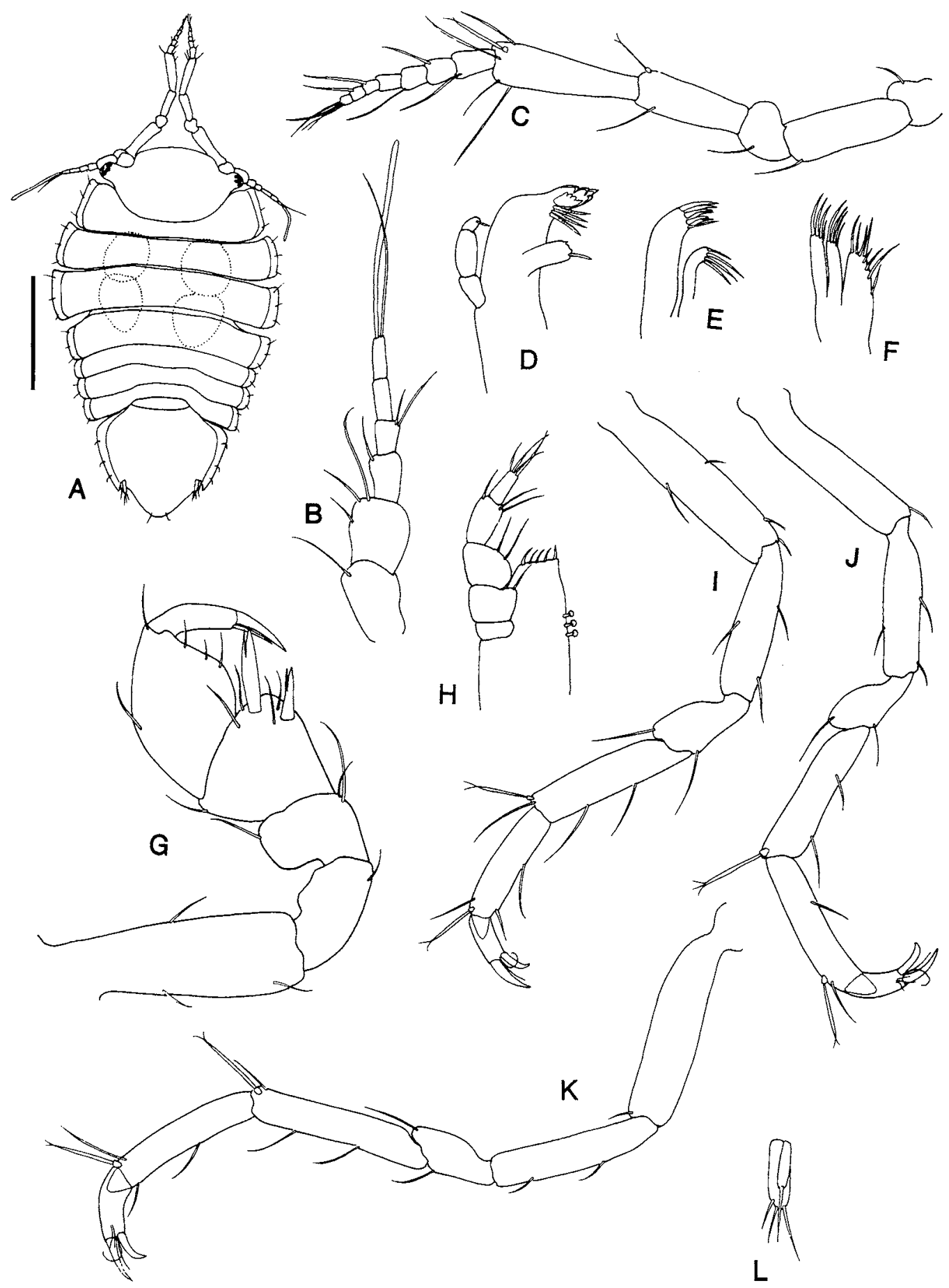

Figure 12. Paramunna pellucida, n. sp. $A$, Paratype ovigerous $\&$, scale $=0.2 \mathrm{~mm} ; B$, antennule; $C$, antenna; $D$, mandible; $E$, maxilla $1 ; F$, maxilla 2 ; $G$, pereopod $1 ; H$, maxilliped; $I$, pereopod $2 ; \mathcal{F}$, pereopod $5 ; K$, pereopod $7 ; L$, uropod. 


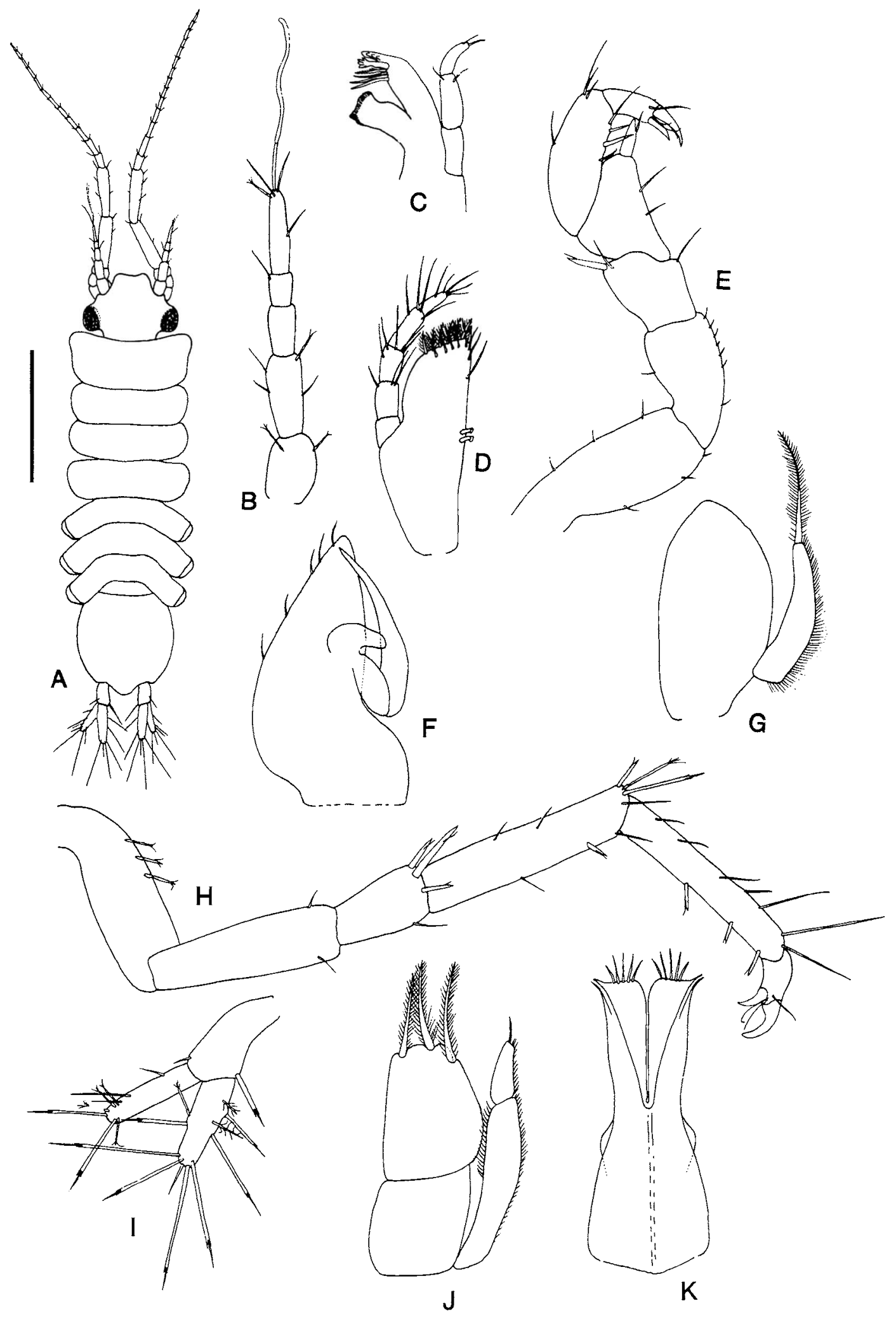


REMARKS: With only females available, the description of this species is of necessity incomplete. Nevertheless, the distinctive transparent flange of the pereon and pleotelson, the latter ending in a single posterior tooth on each side, serve to distinguish this species from the 27 described species (see Winkler 1994, Kensley and Schotte 1996). Species of the genus seem to be primarily austral in distribution, with 19 coming from Antarctic and subantarctic regions and the remainder from South Africa, the North Atlantic, and Japan.

eTYMology: Pellucida (transparent), referring to the transparent lateral flange on the pereon and pleotelson.

\section{Family SantiIdaE}

Genus Santia Sivertsen \& Holthuis, 1980

Santia longisetae Kensley, n. sp.

Figure 13

MATERIAL EXAMINED: Holotype: AMNH 18409, 1 oै, $1.8 \mathrm{~mm}$, Tongariki, coll. C. Boyko and J. Tancredi, 22 August 1999. Paratypes: AMNf 18410, sta. 12A4, Puu Kiri Ohio Point, Anakena Beach, 1 of, $1.6 \mathrm{~mm}$ (dissected on slide), 2 ovigerous $9,1.2 \mathrm{~mm}$, $1.5 \mathrm{~mm}$, coll. J. Quillen, 22 August 1998. Paratypes: UsNm 1008961, sta. 5.3, Oroi Point, 1 o, $1.5 \mathrm{~mm}, 1$ \&, $1.3 \mathrm{~mm}$, coll. J. Quillen, 21 August 1998. AmNH 18411, sta. 4.1, Akahanga, 1 ovigerous $+, 1.3 \mathrm{~mm}, 1$ juvenile, coll. A. Pianetti, 20 August 1998. AMNH 18412, sta. 4.2, Akahanga, $20,1.1$ $\mathrm{mm}, 1.5 \mathrm{~mm}$, coll. A. Pianetti, 20 August 1998. AмN н 18413, sta. 4.4, Akahanga, 1 ; $1.5 \mathrm{~mm}$, coll. Yuko Haoa Avaka, 20 August 1998. Амлн 18414, sta. 5.1, Oroi Point, 1 đ, damaged, 1 ㅇ, $1.3 \mathrm{~mm}$, coll. V. Killorin, 21 August 1998. AMNH 18415, sta. 5.3, Oroi Point, 1 of, $1.4 \mathrm{~mm}$, coll. J. Quillen, 21 August 1998. AmNh 18416, sta. 7.2, Punakapi Point, Te Raha, $1 \hat{\jmath}, 1.5 \mathrm{~mm}, 1$ ovigerous,+ 1.1 mm, 1 ㅇ, $1.2 \mathrm{~mm}$, coll. V. Killorin, 21 August 1998. AмNн 18417, sta. 9.1, Ataranga Bay, 1 9, $1.2 \mathrm{~mm}$, coll. A. T. Pianetti, 23 August 1998. AMNH 18418, sta. 9.3, Ataranga Bay, 1
ㅇ, $1.5 \mathrm{~mm}$, coll. V. Killorin, 23 August 1998. AMNH 18419, sta. 9.5, Ataranga Bay, 1 , 0.9 mm, coll. V. Killorin, 23 August 1998. AMNH 18420, sta. 9.6, Ataranga Bay, 1 \&, $1.5 \mathrm{~mm}$, coll. J. S. Friedman, 23 August 1998. AMNH 18421, sta. 10.1, La Perouse Bay, 1 đo, 1.6 $\mathrm{mm}, 1$ ovigerous o, $1.7 \mathrm{~mm}$, coll. J. Quillen, 21 August 1998. AMnH 18422, sta. 12A.2, Puu Kiri Ohio Point, Anakena Beach, 1 \&, 1.0 mm, coll. J. Quillen, 22 August 1998.

Description: Male: Body about 3 times longer than greatest width at pereonites 5 and 6. Cephalon narrower than pereonite 1 , anterior margin between antennal bases slightly concave. Pereonite 1 longer than remaining pereonites. Coxae visible on pereonites 5-7. Pleonite 1 short, lacking free lateral margins. Pleotelson as long as wide, lateral margins evenly convex, posterior margin between uropodal bases strongly convex.

Antennule consisting of 5 articles, basal article widest, shorter than article 2; terminal article twice length of subterminal, bearing single distal aesthetasc. Antenna with articles $1-3$ of peduncle short, articles 4 and 5 subequal, elongate slender; flagellum of about 15 articles. Mandibular palp of 3 articles, distal article curved; molar distally truncate, broad; 4 setae in setal row; lacinia mobilis with 5 cusps; incisor having 4 cusps. Maxillipedal palp consisting of 5 narrow setose articles; endite bearing 6 fringed setae along distal margin plus 5 simple setae submarginally; two coupling hooks present. Pereopod 1 shorter than remaining legs, carpo-chelate; merus having single stout sensory seta anterodistally; carpus roughly triangular, with stout sensory seta on posterodistal rounded lobe; propodus with few setae on palm; dactylus with strong primary unguis plus shorter but strong secondary unguis. Pereopods $2-7$ similar, posterior pereopods becoming longer; merus with 2 or 3 stout sensory setae on distal margin; carpus about 2.3 times longer than merus, with several elongate sensory setae distally; propodus subequal in length to carpus, with 2 or 3 short sensory setae on posterior margin;

Figure 13. Santia longisetae, n. sp. $A$, Paratype ${ }^{A}$ in dorsal view, scale $=0.5 \mathrm{~mm} ; B$, antennule; $C$, mandible; $D$, maxilliped; $E$, pereopod $1 ; F$, pleopod 2; $G$, pleopod 4; $H$, pereopod $7 ; I$, uropod; $\mathcal{F}$, pleopod $3 ; K$, pleopod 1. 
dactylus with strong primary and shorter stout secondary unguis. Pleopod 1, rami fused for about half length, each ramus distally rounded truncate, bearing 5 simple setae distally, distolateral corner narrow, spoutlike. Pleopod 2 having few setae along lateral margin of protopod, endopod slender, tapering, almost reaching apex of protopod. Pleopod 3 protopod and single article of endopod broad, 2.5 times wider than exopod, with 3 setulose setae distally; exopod with distal article about one-fourth length of proximal article, both articles finely setulose along lateral margin. Pleopod 4 with broad lamellar endopod about 3.5 times wider than exopod; latter tapering distally, bearing single setulose seta distally. Uropodal protopod subequal in length to exopod, with single tridentlike seta mesiodistally; exopod with 2 elongate tridentlike setae and several short brush setae distally; endopod slightly wider than, but subequal in length to exopod, with about 7 elongate trident setae on mesial, distal, and lateral margins.

Ovigerous female: Broader than male, widest at pereonite 3 .

REMARKS: The new material most closely resembles $S$. dimorphis (Menzies, 1962) from Islas Guaitecas, southern Chile, but differs in the following characters: Pereopod 1 in the male has a proportionately shorter propodus bearing fewer setae on the palm; the uropodal exopod in $S$. dimorpbus is longer than the endopod, with about 10 elongate distal setae; in the new species the uropodal rami are subequal in length, and the exopod bears fewer but more elongate setae.

ETYMoLOgY: The Latin longisetae refers to the elongate setae on the uropodal rami.

\section{Suborder Flabellifera \\ Family CirolanidaE \\ Genus Metacirolana Nierstrasz, 1931}

\section{Metacirolana sp.}

Material examined: 1 juvenile, Motu Iti, from Pocillopora coral, $52 \mathrm{~m}$, coll. $\mathrm{H}$. Tonnemacher, 28 August 1999.

REMARKS: Because the single specimen available is immature, no further identification is possible.

\section{Family Sphaeromatidae \\ Genus Exospbaeroides Holdich \& Harrison, 1983}

Exosphaeroides quadricosta Kensley, n. sp.

Figures 14, 15

MATERIAL EXAMINED: Holotype: AMNH 18423, immature $\sigma^{\star}, 2.2 \mathrm{~mm}$, Tongariki, freshwater pool in stone basin near tide pools, coll. C. Boyko et al., 22 August 1999. Paratype: AMNH 18424, immature, $2.5 \mathrm{~mm}, 3.0$ $\mathrm{mm}$, sta. 4.1, Akahanga, coll. A. Pianetti, 20 August 1998. AMNH 18425, 1 immature, 2.0 $\mathrm{mm}$, sta. 4.4, Akahanga, coll. Yuko Haoa Avaka, 20 August 1998.

DESCRIPTION: Dorsal surface of body finely setulose. Cephalon dorsally rugose, with rounded ridge along posterior margin; frontal lamina distally rounded, setose, arms short, blunt. Pereonites 1-6 each with raised rounded ridge along posterior margin, having rounded tubercle laterally, coxa with low elongate rounded tubercle. Pereonite 7 lacking ridge or tubercles. Fused pleon with 4 rounded tubercles; pleotelson with 4 rounded elongate tubercles in anterior half, apex narrowly rounded, ventrally with shallow channel.

Antennule with basal article largest, flexed, outer surface finely setose; article 2 about one-third length of basal article; article 3 slightly longer than and half width of article 2; flagellum of 6 articles, with single aesthetasc on articles 3, 4, and 5. Antennal peduncle with 3 basal articles short, subequal, 2 distal articles more elongate; flagellum of 9 setose articles. Mandibular incisor having 2 stout sclerotized cusps, lacinia having 3 sclerotized cusps; 4 fringed setae in setal row; molar broadly lobed, with marginal acute scales; palp of 3 articles, articles 1 and 2 subequal in length, 2 with 2 elongate distal setae on lateral margin; article 3 shorter than 2, with 8 setae on distolateral margin increasing in length distally. Maxillipedal endite bearing 4 blunt setae and several fringed interspersed setae on distolateral curved margin, acute triangular setae at mesiodistal angle, mesial margin with 2 elongate fringed setae, single coupling hook; palp of short basal article, article 2 longest, distomesial lobe setae; articles 

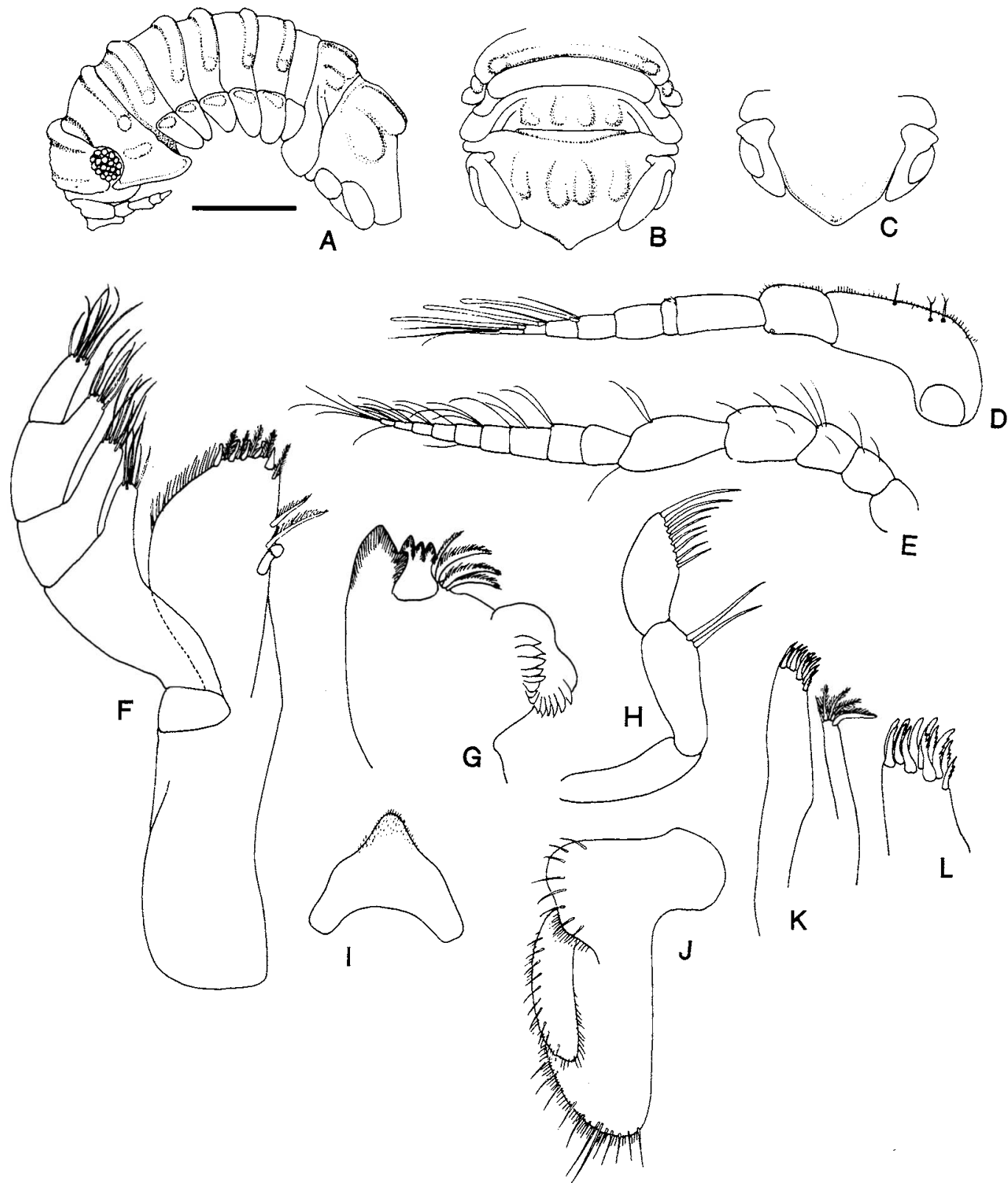

Figure 14. Exosphaeroides quadricosta, n. sp. $A$, Holotype immature ${ }^{*}$ in lateral view, scale $=0.5 \mathrm{~mm} ; B$, holotype pleon in dorsal view; $C$, pleotelson and uropods in ventral view; $D$, antennule; $E$, antenna; $F$, maxilliped; $G$, mandible; $H$, mandibular palp; $I$, frontal lamina; $\mathcal{F}$, uropod; $K$, maxilla $1 ; L$, maxilla 1 , apex of lateral ramus enlarged.

3 and 4 similar, each with setose distomesial lobe; article 5 relatively slender, with cluster of apical setae. Pereopod 1, carpus triangular, with 2 stout setae on posterior margin; pro- podus about 2.5 times longer than wide, with 3 stout setae on posterior margin; dactylus with short stout accessory unguis. Pereopod 2 , carpus twice longer than wide, with 3 distal 
fringed stout setae; propodus 2.5 times longer than wide, with 2 setae on posterior margin; dactylus with short stout accessory unguis. Pereopod 7, merus and carpus setose on posterior margins; carpus with 2 fringed stout setae distally. Pleopod 1, protopod with 3 coupling hooks; endopod longer than exopod, elongate triangular, mesial margin straight, with plumose marginal setae on distolateral margin; exopod elongate ovate, distally rounded, distolateral margin bearing plumose marginal setae. Pleopod 2, copulatory stylet visible within endopod, latter broad-based, tapering distally; exopod broadly ovate. Pleopods 4 and 5, rami lacking obvious pleats; endopod triangular, with small distal article; exopod roughly ovate, two-thirds length of endopod. Pleopod 5 endopod with 2 distal scale-bearing bosses and incomplete distal suture; exopod shorter than endopod, with distolateral margin finely setose. Uropod with protopod and endopod fused, latter elongate ovate with setose lateral and distal margin; exopod one-third width and about half length of endopod, lateral margin setose.

REMARKS: As with so many small sphaeromatid species, generic placement for the new material is problematic. The lack of transverse folds on pleopods 4 and 5 , the pleonal suture lines running to the posterior and not the lateral pleonal margin, and the somewhat reduced uropodal exopod suggest an affinity with the "platybranchiate" group of species. Using Harrison and Ellis' key (1991), one arrives at the monotypic genus Exosphaeroides Holdich \& Harrison, 1983, for the new material, but the nature of the penes is unknown, and the uropodal rami are rather more developed in E. fuvialis Holdich \& Harrison, 1983. For want of more mature material of both sexes, and because of the uncertainty of sphaeromatid systematics, the new species is placed in Exosphaeroides in the full knowledge that this is merely a placement of convenience and a way of recording the presence of this species.

The new material bears some resemblence to Paracassidinopsis sculpta Nobili, 1906 (see Müller 1991:91), in the four ridges on the pleotelson, but the frontal lamina, uropods, and pleopods 4 and 5 all differ.
ETYMology: The specific name, meaning four ridges or ribs, refers to the four rounded ridges of the pleotelson.

\section{DISCUSSION}

The tiny speck of Easter Island lies in the South Pacific Ocean, $3800 \mathrm{~km}$ from the South American mainland to the east and about $2200 \mathrm{~km}$ from Ducie and Henderson Islands in the Pitcairn group, its nearest neighbors to the west. It is generally agreed that the marine fauna of the island is IndoWest Pacific in affinity but depauperate (Rehder 1980, DiSalvo et al. 1988). Volcanic in origin, about 2.5 million yr in age (Whatley et al. 2000), washed by relatively cold water in which hermatypic corals occur but do not form reefs, with heavy surf through most of the year, and large numbers of grazing fishes and sea urchins, the shallow marine environment offers fewer microhabitats in which small invertebrates may shelter than is seen for more tropical islands. C. B. Boyko (pers. comm., 2001) noted that there are large reefs present, composed of very few coral species, but which never break the water surface. DiSalvo et al. (1988) considered that the major marine communities begin only below $10 \mathrm{~m}$.

The marine crustacean fauna of Easter Island, even though probably depauperate for an Indo-Pacific island, is not well known. DiSalvo et al. (1988) listed about 50 species of cirripedes, amphipods, isopods (two unidentified species of Dynamenella), caridean shrimps, stomatopods, crabs, and anomurans. Since that paper, Whatley et al. (2000) recorded 31 species of ostracodes, of which 24 (77\%) were regarded as endemic to Easter Island, and two species also known from the Pitcairn group. Botosaneanu (1987) described the blind anthurid isopod Cyatbura (Stygocyathura) rapanuia, taken from $40-$ to $55-\mathrm{cm}$ depth in volcanic sand at midtide level on the shore of Easter Island and recorded a second specimen, also from volcanic shore sand, from Pitcairn Island. Boyko and Williams (2001) described the parasitic bopyrid isopod Pseudionella akuaku from the hermit crab Calcinus imperialis Whitelegge, taken from the intertidal of Easter Island. 


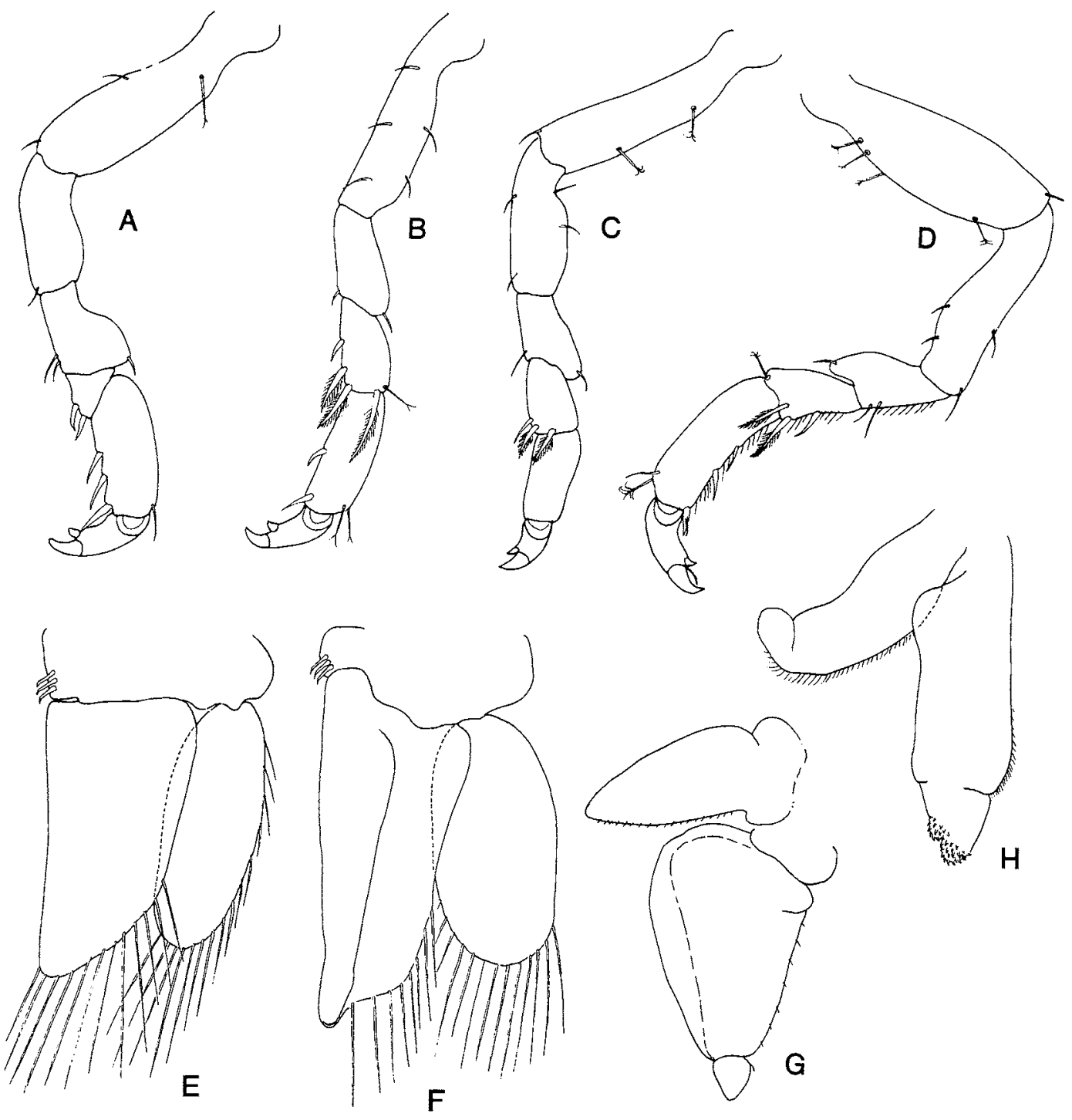

Figure 15. Exosphaeroides quadricosta, n. sp. $A$, Pereopod 1; $B$, pereopod 2; $C$, pereopod 6; $D$, pereopod 7; $E$, pleopod 1; $F$, pleopod 2 immature of; $G$, pleopod $4 ; H$, pleopod 5 .

In this paper, 13 species of isopods are described as new, and a further seven species are identified only to generic level. These are in the suborders Anthuridea (six species), Asellota (11 species), and Flabellifera (two species). Aside from the Exosphaeroides, about which little is known, all the other genera are widespread and commonly found in shallowwater habitats in the Tropics and subtropics of the Indian, Atlantic, and Pacific Oceans (see Kensley 1998). With the possible exception of the Carpias, the species are regarded as endemic, only insofar as the cryptic shallow marine fauna of much of the Pacific is poorly or barely known, giving a level of endemicity for the isopods of over $90 \%$. Because none of the Carpias specimens was a mature male, specific identification was not possible, but 
they resemble C. algicola (Miller, 1941), originally described from Hawai'i but known to be widespread in the Pacific, Atlantic, and Indian Oceans, perhaps through rafting on algae or transport on algae on ships' hulls.

This collection of isopods is notable for the small size of all the species. The largest species is Parantbura nordenstami at $7.9 \mathrm{~mm}$, and the majority, the asellotes, are in the 1- to $2-\mathrm{mm}$ range or less. This size range suggests that the animals are all cryptic in habit, living in the interstices of sand and coral grains, thereby avoiding the stress of high wave action and scouring, which affects even the tide pools at the top of the shore. The most common species in the samples, Santia longisetae, was recorded from 15 separate stations, suggesting that the species probably occurs on several substrate types.

The single station from deeper water, that of a sample taken from Pocillopora sp. coral in $52 \mathrm{~m}$, shows the highest diversity, with eight species, including five asellote species. All are less than $3 \mathrm{~mm}$ in total length, suggesting that, even though below the major effects of wave action, the cryptic habit is still the rule, perhaps as a strategy for avoiding fish predators.

\section{ACKNOWLEDGMENTS}

I am grateful to Christopher Boyko (American Museum of Natural History) for making this collection of isopods available for study and for providing collection data and general information on Easter Island. I thank the several collectors mentioned in the Appendix for their efforts in procuring the isopod specimens.

\section{Literature Cited}

Barnard, K. H. 1914. Contributions to the crustacean fauna of South Africa. 3. Additions to the marine Isopoda, with notes on some previously incompletely known species. Ann. S. Afr. Mus. 10 (11): 325a442.
Anthuridae (Crustacea: Isopoda) with remarks on certain morphological peculiarities. J. Linn. Soc. Lond. Zool. 36:109160.

Bate, C. S., and J. O. Westwood. 1868. A history of the British sessile-eyed Crustacea. John van Voorst, London. Ivi + $536 \mathrm{pp}$.

Botosaneanu, L. 1987. A new thalassostygobiont species of Cyatbura (Isopoda: Anthuridea) from the south-east Pacific. Stygologia 3 (4): 296-304.

Boyko, C. B., and J. D. Williams. 2001. A review of Pseudionella Shiino, 1949 (Crustacea: Isopoda: Bopyridae), with the description of a new species parasitic on Calcinus hermit crabs from Easter Island. Proc. Biol. Soc. Wash. 114 (3): 649-659.

DiSalvo, L. H., J. E. Randall, and A. Cea. 1988. Ecological reconaissance of the Easter Island sublittoral marine environment. Nat. Geogr. Res. 4 (4): 451-473.

Fresi, E., and M. B. Scipione. 1980. Maresiella nomen novum pro Maresia Fresi, 1973, a gnathostenetroid asellote isopod from the Galapagos Islands. Pages 313-314 in Galapagos: Studi e richerche. Spedizione "L. Mares-G.RT.S.T.S." Gruppo Richerche Scientifiche e Tecniche Subacquee, Florence.

Harrison, K., and J. P. Ellis. 1991. The genera of the Sphaeromatidae (Crustacea: Isopoda): A key and distribution list. Invertebr. Taxon. 5:915-952.

Haswell, W. A. 1884. On a new crustacean found inhabiting the tubes of Vermilia (Serpulidae). Proc. Linn. Soc. N.S.W. 9 (3): 676-680.

Holdich, D. M., and K. Harrison. 1983. Sphaeromatid isopods (Crustacea) from brackish waters in Queensland, Australia. Zool. Scr. 12 (20): 127-140.

Just, J. 2001. Bathyal Joeropsididae (Isopoda: Asellota) from south-eastern Australia, with description of two new genera. Mem. Mus. Vict. 58 (2): 297-334.

Kensley, B. 1979. New species of anthurideans from the Cook and Fiji Islands (Crustacea: Isopoda: Anthuridea). Proc. Biol. Soc. Wash. 92 (4): 814-836.

1925. A revision of the family
. 1998. Estimates of species diversity 
of free-living marine isopod crustaceans on coral reefs. Coral Reefs 17:83-88.

Kensley, B., and R. W. Heard. 1991. Studies on the Crustacea of the Turks and Caicos Islands, British West Indies I. Four new marine isopod crustaceans from the vicinity of Pine Cay. Gulf Res. Rep. 8 (3): 237246.

Kensley, B., and M. Schotte. 1996. World list of marine, freshwater and terrestrial isopods. www.nmnh.si.edu/iz/isopod/.

Koehler, R. 1885. Description d'un isopode nouveau, le Foeropsis brevicornis. Ann. Sci. Nat. Paris, Zool. (6) 19:1-7.

Kröyer, H. 1839. Munna en ny kraebsdyrslaegt. Naturh. Tids. Kjob. 2:612-616.

Menzies, R. J. 1962. Reports of the Lund University Chile Expedition 1948-1949. The zoogeography, ecology, and systematics of the Chilean marine isopods. Lunds Univ. Arsskr., n.f. 2, vol. 57 (11): 1162.

Miller, M. A. 1941. The isopod Crustacea of the Hawaiian Islands, II. Asellota. Occas. Pap. Bernice Pauahi Bishop Mus. 16:305320.

Miller, M. A., and R. J. Menzies. 1952. The isopod Crustacea of the Hawaiian Islands III. Superfamily Flabellifera, Family Anthuridae. Occas. Pap. Bernice Pauahi Bishop Mus. 21 (1): 1-15.

Müller, H.-G. 1989. Joeropsidae from Bora Bora and Moorea, Society Islands, with descriptions of four new species (Isopoda: Asellota). Bijdr. Dierkd. 59 (2): 71-85.

1990. Two new species and a new genus of coral-reef-inhabiting Munnidae from Bora Bora and Moorea, Society Islands (Crustacea: Isopoda). Rev. Suisse Zool. 97 (2): 361-371.

1991. Sphaeromatidae from coral reefs of the Society Islands, French Polynesia (Crustacea: Isopoda). Cah. Biol. Mar. 32:83-104.

Nierstrasz, H. F. 1931. Die isopoden der Siboga-Expedition. III. Isopoda genuina II. Flabellifera. Siboga Expedition Monograph 32c:123-232.

Nobili, G. 1906. Diagnoses préliminaires des crustacés, decapodes et isopods nouveaux recueillis par M. le Dr. G. Seurat aux îles
Touamotou. Bull. Mus. Natl. Hist. Paris 12:256-270.

Nordenstam, A. 1930. Tanaidacea and marine Isopoda from Juan Fernandez. Pages 525-552 in C. Skottsberg, ed. The natural history of Juan Fernandez and Easter Island. Vol. 3. Zoology, part 4, number 54. Almqvist and Wiksells, Uppsala.

- 1933. Marine Isopoda of the families Serolidae, Idotheidae, Pseudidotheidae, Arcturidae, Parasellidae and Stenetriidae, mainly from the South Atlantic. Further Zoological Results of the Swedish Antarctic Expedition 1901-1903, 3:1-284.

Poore, G. C. B. 1984a. Colanthura, Califantbura, Crurantbura and Cruregens, related genera of the Paranthuridae (Crustacea: Isopoda). J. Nat. Hist. 18:697-715.

. 1984b. Parantbura (Crustacea, Isopoda, Paranthuridae) from south-eastern Australia. Mem. Mus. Vict. 45:33-69.

-1984c. Redefinition of Munna and Uromunna (Crustacea: Isopoda: Munnidae), with descriptions of five species from coastal Victoria. Proc. R. Soc. Victoria 96:61-81.

Poore, G. C. B., and B. Kensley. 1981. Coralanthura and Sauranthura, two new genera of anthurideans from northeastern Australia (Crustacea: Isopoda: Anthuridae). Proc. Biol. Soc. Wash. 94 (2): 503-513.

Rehder, H. A. 1980. The marine mollusks of Easter Island (Isla de Pascua) and Sala y Gomez. Smithson. Contrib. Zool. 289:1167.

Richardson, H. 1902. The marine and terrestrial isopods of the Bermudas, with descriptions of new genera and species. Trans. Conn. Acad. Arts Sci. 11:277310.

Sars, G. O. 1866. Beretning om en i Sommeren 1865 foretagen zoologisk Reise ved Kysterne af Christianias og Christianssands Stifter. Christiania. $47 \mathrm{pp}$.

-1 1905. Pacifische Plankton-Crustaceen (Ergebnisse einer Reise nach dem Pacific. Schauinsland 1896-1897). II. Brackwasser-Crustaceen von den Chatham-Inseln. Zool. Jahrb., Abt. Syst., Geogr. Biol. Tiere 21:371-414.

Schultz, G. A. 1977. Anthurids from the west 
coast of North America, including a new species and three new genera (Crustacea, Isopoda). Proc. Biol. Soc. Wash. 90:839848.

Sivertsen, E., and L. B. Holthuis. 1980. The marine isopod Crustacea of the Tristan da Cunha Archipelago. Gunneria 35:1-128.

Stebbing, T. R. R. 1900. On Crustacea brought by Dr. Willey from the South Seas. Willey's Zool. Res. 5:605-690.

Whatley, R., R. Jones, and K. Wouters. 2000. The marine Ostracoda of Easter Island. Rev. Esp. Micropaleontol. 32 (1): 79-106. Winkler, H. 1994. Paramunnidae (Crustacaea: Isopoda: Asellota) from the Magellan Strait. Zool. J. Linn. Soc. 110:243-296.

\section{Appendix}

Easter Island Station List with Isopod Records

\begin{tabular}{|c|c|c|c|}
\hline Station & Locality/Species & Date & Collector \\
\hline 2.1 & $\begin{array}{l}\text { Hanga Poukura } \\
\text { Sphaeromatid }\end{array}$ & 20 August 1998 & A. Pianetti \\
\hline 2.2 & $\begin{array}{l}\text { Hanga Poukura } \\
\text { Uromunna biloba }\end{array}$ & 20 August 1998 & A. Pianetti \\
\hline 2.3 & $\begin{array}{l}\text { Hanga Poukura } \\
\text { Carpias sp. } \\
\text { Saurantbura rapanui } \\
\text { Sphaeromatid }\end{array}$ & 20 August 1998 & A. Pianetti \\
\hline 2.3 .2 & $\begin{array}{l}\text { Hanga Poukura } \\
\text { Panathura sp. } \\
\text { Parantbura sp. }\end{array}$ & 20 August 1998 & A. Pianetti \\
\hline 3.1 & $\begin{array}{l}\text { Hanga Tee } \\
\text { Carpias sp. }\end{array}$ & 20 August 1998 & A. Pianetti \\
\hline 3.3 .2 & $\begin{array}{l}\text { Hanga Tee } \\
\text { Carpias sp. }\end{array}$ & 20 August 1998 & A. Pianetti \\
\hline 4.1 & $\begin{array}{l}\text { Akahanga } \\
\text { Exospbaeroides quadricosta } \\
\text { Foeropsis acoloris } \\
\text { Santia longisetae }\end{array}$ & 20 August 1998 & A. Pianetti \\
\hline 4.2 & $\begin{array}{l}\text { Akahanga } \\
\text { Santia longisetae } \\
\text { Saurantbura rapanui }\end{array}$ & 20 August 1998 & A. Pianetti \\
\hline 4.3 & $\begin{array}{l}\text { Akahanga } \\
\text { Sphaeromatid }\end{array}$ & 20 August 1998 & A. Pianetti \\
\hline 4.4 & $\begin{array}{l}\text { Akahanga } \\
\text { Exosphaeroides quadricosta } \\
\text { Santia longisetae }\end{array}$ & 20 August 1998 & Yuko Haoa Avaka \\
\hline 5.1 & $\begin{array}{l}\text { Oroi Point } \\
\text { Carpias sp. } \\
\text { Santia longisetae }\end{array}$ & 21 August 1998 & V. Killorin \\
\hline 5.2 & $\begin{array}{l}\text { Oroi Point } \\
\text { foeropsis acoloris }\end{array}$ & 21 August 1998 & J.S. Friedman \\
\hline 5.3 & $\begin{array}{l}\text { Oroi Point } \\
\text { Carpias sp. } \\
\text { foeropsis acoloris } \\
\text { Santia longisetae }\end{array}$ & 21 August 1998 & J. Quillen \\
\hline 7.2 & $\begin{array}{l}\text { Punakapi Point, Te Raha } \\
\text { Carpias sp. } \\
\text { Santia longisetae } \\
\text { Stenetriid }\end{array}$ & 21 August 1998 & V. Killorin \\
\hline 8.1 & $\begin{array}{l}\text { Yama Point } \\
\text { Asellote (?Iais sp.) } \\
\text { Sauranthura rapanui }\end{array}$ & 21 August 1998 & J.S. Friedman \\
\hline
\end{tabular}


Appendix (continued)

\begin{tabular}{|c|c|c|c|}
\hline Station & Locality/Species & Date & Collector \\
\hline $8 \mathrm{~A} .1$ & $\begin{array}{l}\text { Nui Bay } \\
\text { Asellote }\end{array}$ & 24 August 1998 & V. Killorin \\
\hline 9.1 & $\begin{array}{l}\text { Ataranga Bay } \\
\text { Carpias sp. } \\
\text { Santia longisetae }\end{array}$ & 23 August 1998 & A. Pianetti \\
\hline 9.3 & $\begin{array}{l}\text { Ataranga Bay } \\
\text { foeropsis acoloris } \\
\text { Santia longisetae }\end{array}$ & 23 August 1998 & V. Killorin \\
\hline 9.5 & $\begin{array}{l}\text { Ataranga Bay } \\
\text { Carpias sp. } \\
\text { Santia longisetae }\end{array}$ & 23 August 1998 & V. Killorin \\
\hline 9.6 & $\begin{array}{l}\text { Ataranga Bay } \\
\text { Santia longisetae }\end{array}$ & 23 August 1998 & J. S. Friedman \\
\hline 10.1 & $\begin{array}{l}\text { La Perouse Bay } \\
\text { Santia longisetae } \\
\text { Sphaeromatid }\end{array}$ & 21 August 1998 & J. Quillen \\
\hline $12 \mathrm{~A} .2$ & $\begin{array}{l}\text { Puu Kiri Ohio Point, Anakena Beach } \\
\text { Apantbura sp. } \\
\text { Santia longisetae }\end{array}$ & 22 August 1998 & J. Quillen \\
\hline \multirow[t]{7}{*}{12 A. 4} & $\begin{array}{l}\text { Puu Kiri Ohio Point, Anakena Beach } \\
\text { Carpias sp. } \\
\text { Santia longisetae } \\
\text { Sphaeromatid }\end{array}$ & 22 August 1998 & J. Quillen \\
\hline & $\begin{array}{l}\text { Tongariki (Morit freshwater pool) } \\
\text { Asellote } \\
\text { Exosphaeroides quadricosta } \\
\text { Joeropsis limbatus } \\
\text { Joeropsis trilabes } \\
\text { Santia longisetae } \\
\text { Uromunna biloba }\end{array}$ & 22 August 1999 & C. Boyko, J. Tancredi \\
\hline & $\begin{array}{l}\text { Hanga Tee O Vaihu } \\
\text { Carpias sp. } \\
\text { Joeropsis bicornis } \\
\text { Paranthura nordenstami } \\
\text { Uromunna biloba }\end{array}$ & 24 August 1999 & C. Boyko, J. Tancredi \\
\hline & $\begin{array}{l}\text { Motu Iti, from Pocillopora, } 52 \mathrm{~m} \\
\text { Asellote } \\
\text { Califanthura dodecaseta } \\
\text { Eisotbistos sp. } \\
\text { 7oeropsis limbatus } \\
\text { Metacirolana sp. } \\
\text { Munna sp. } \\
\text { Paramunna pellucida } \\
\text { Salvatiella islapascua }\end{array}$ & 28 August 1999 & H. Tonnemacher \\
\hline & $\begin{array}{l}\text { Ahu Te Peu } \\
\text { Asellote } \\
\text { Califantbura dodecaseta }\end{array}$ & 29 August 1999 & H. Tonnemacher \\
\hline & $\begin{array}{l}\text { Piko, from coral } \\
\text { 7oeropsis trilabes } \\
\text { Mesanthura pascuaensis } \\
\text { Uromunna biloba }\end{array}$ & 31 August 1999 & C. Boyko, S. Reanier \\
\hline & $\begin{array}{l}\text { Moai Tide Pool } \\
\text { 7oeropsis bicornis } \\
\text { Foeropsis trilabes } \\
\text { Uromunna biloba }\end{array}$ & 25 August 1999 & C. Boyko \\
\hline
\end{tabular}

